\title{
Public Choice at the Dawn of the Special Interest State: The Story of Butter and Margarine
}

\author{
Geoffrey P. Miller†
}

Nothing on earth, save the virtue of woman, is more susceptible to scandal than butterfat.

W.D. Hoard ${ }^{1}$

Few substances seem as innocuous as the prosaic table spread and shorteining agent oleomargarine. Yet for over three quarters of a century, between the 1870 s and the 1950 s, margarine was the victim of a sustained and concerted pattern of discrimination by the national government and almost every state in the union. The antimargarine laws that resulted were the construct of a powerful, highly sophisticated special interest: the American dairy industry.

The story of these laws-and of the margarine industry's struggle against them-in many respects epitomizes the growth and development of special interest pohtics im the United States. Indeed, the initial battles in the margarine war provide some of the earhest examples of special interest lobbymg by one domestic industry for federal protection against conipetition from another, less powerful, domestic industry.

This Article provides a history of the first battle in the margarine war, ${ }^{2}$ which culminated in the passage of the federal Oleomargarine Act

Copyright $($ ) 1989 by Geoffrey Miller. All rights reserved.

$\dagger$ Associate Dean and Professor of Law, University of Chicago Law School; A.B. 1973, Princeton University; J.D. 1978, Columbia University.

I would like to thank the participants at faculty workshops at Washington and Northwestern University Law Schools for their helpful comments, Linda Brinker, Brian Hedlund, and Leon Greenfield for valuable research help, the John M. Olin Foundation for financial assistance, and Randall R. Lee of the CALIFORNIA LAw REview for outstanding editorial work.

1. G. RANkin, William Dempster HoARd 180 (1925) (quoting William Dempster Hoard, Governor of Wisconsin from 1888 to 1891 and a leading nineteenth-century dairyman).

2. Surprisingly, there appears to be no general history of the margarine controversy. The matter is treated in passing in E. LAMPARD, THE RISE OF THE DAIRY INDUSTRY IN WISCONSIN: A Study of AGRicultural ChaNGe 1820-1920, at 257-66 (1963). This outstanding work, however, focuses only on the controversy's aspects affecting Wisconsin dairy interests. A few works discuss the controversy in general comparisons of margarine and butter. See W. PABST, BuTTER AND Oleomargarine: AN ANalysis of COMPETINg Commodities (Studies in History, Economics and Public Law No. 427, 1937); K. SNOdgrass, MARgarine AS A BuTTER Substitute (Fats and Oils Studies No. 4, 1930); E. W1EST, THE BuTrer INDUSTRY IN THE UNITED STATES (Studies in History, Economics and Public Law No. 165, 1916); see also W. MCCunE, The FARM BLoc (1943) (describing the dairy lobby's campaign against inargarine in the early 1940s); M. OKUN, FAIR PLAY 


\section{of $1886 .{ }^{3}$ Intended as an application of the theory of public choice to one}

IN THE MARKETPLACE 250-86 (1986) (describing aspects of the controversy relevant to the battle over pure food and drug laws, especially in New York); S. Riepma, The Story of Margarine (1970) (reviewing the subject in a general treatise on margarine as a commodity from a promargarine perspective). A few law review articles examine the matter from the standpoint of legal doctrine. See Storke, Oleomargarine and the Law, 18 RockY MTN. L. REv. 79 (1946); Note, Oleomargarine and the Constitution, 10 MoNT. L. REV. 46 (1949); Note, The Oleomargarine Controversy, 33 VA. L. REV. 631 (1947). A useful compendium of margarine statutes is found in S. Zwick, The Effects of Certain Supreme Court Decisions upon State Margarine Policies (1950) (unpublished inaster's dissertation).

3. Oleoinargarine Act of 1886 , ch. 840,24 Stat. 209. See infra text accoinpanying notes 203270.

The dairy industry's campaign against butterfat substitutes lasted froin the 1870 s through the 1950s (and even into the 1960 s in a few major dairy states). When the legislation described in this Article proved ineffective, the dairy industry organized a new campaign at both the state and federal levels intended to discourage margarine sales by regulating the product's color, either by forbidding yellow margarine or by mandating that margarine be colored pink. See K. SNODGRAss, supra note 2, at 90-91. The federal Oleoinargarine Act of 1902, ch. 784, 32 Stat. 193, inposed a prohibitive tax on colored margarine, thus effectively requiring that margarine sold in interstate coinmerce remain in its "natural" (white) color. This law hampered the margarine industry because consumers would not buy white margarine. However, the industry circumvented these "white" laws by using special fats that gave inargarine a naturally yellow tinge, by including sinall dye packages in the bricks for use in coloring margarine at home, and at least initially by simply disobeying the federal statute. See K. SNODGRASS, supra note 2 at 62-76; 1911 CoMM'R ANN. REP. 17-19. Additionally, an omitted coinina in the 1902 statute, coupled with the developinent of hydrogenation as a technique for solidifying vegetable oils, allowed the development of a huge industry in margarine made from coconut oil, a product not subject to the federal statute and whicli therefore could be sold in colored form. K. SNODGRass, supra note 2, at 78-84. Congress brought "nut" margarine within the federal statute in 1930. Act of July 10, 1930, ch. 882, 46 Stat. 1022. Congress closed the loophole for "naturally" colored margarine in 1931. Act of Mar. 4, 1931, cl. 520, 46 Stat. 1549. Meanwhile, disastrous Depression conditions stimulated a new round of repressive state legislation in the forn of lieavy inargarine taxes. See Storke, supra note 2, at 84.

The political equilibrium clianged dramatically in the following years. Technological developinents permitted cottonseed and soybean oils to becoine inportant ingredients in margarine by the late 1930 s, see S. RIEPMA, supra note 2 , at $124-26$, creating a powerful domestic constituency in favor of inargarine. Butter shortages during the Second World War led to increasing consumer coinplaints about restrictive margarine legislation. Id. Public interest groups lobbied for repeal of the inargarine laws. Id. After a protracted battle, Congress repealed the federal oleomargarine tax in 1950. Act of Mar. 16, 1950, ch. 61, 64 Stat. 20. Margarine legislation was also repealed or judicially invalidated in most states, with the last loldout, Wisconsin, repealing its statute in 1967. Act of May 31, 1967, cl. 42, 1967 Wis. Laws 44. Today, margarine outsells butter by more than two to one. Bureau of the Census, U.S. DePt. of Commerce, Statistical Abstract of the UNITED STATES 114 (1988) (10.8 pounds of margarine and 4.9 pounds of butter consumed per capita in 1985).

In addition to battling against margarine, the dairy industry stoutly resisted coinpetition from unilkfat substitutes in the fluid milk and clieese markets. Congress inposed a prohibitive tax on "fllled cheese" (skimmed-milk clieese laced witl vegetable oil) in 1896, Act of June 6, 1896, ch. 337, 29 Stat. 253, and outlawed the sale of "fllled milk" (evaporated skim milk laced with vegetable oil) in 1923, Filled Milk Act of 1923, 21 U.S.C. $\$ \S 61-64$. The federal fllled-cheese statute was repealed in 1974. Act of Oct. 26, 1974, $\S 3,88$ Stat. 1466. In addition, despite having been twice upheld by the Supreine Court, see Carolene Products Co. v. United States, 323 U.S. 18 (1944), United States v. Carolene Products Co., 304 U.S. 144 (1938), the filled-milk statute has been declared unconstitutional by a federal district court. Milnot Co. v. Richardson, 350 F.Supp. 221 (S.D.Ill. 1972). It is no longer enforced. See Miller, The True Story of Carolene Products, 1987 SuP. CT. Rev. 397 (1987); Strong, A Post-Script to Carolene Products, 5 Const. Comm. 185 (1988). 
set of historical and industrial circumstances, this Article illustrates the subtle and coinplex interplay among pohitics, technology, inarkets, and law in American society.

This study highlights three important probleins in the theory of public choice. ${ }^{4}$ First, it confronts the classic problem of explaining the formation of large groups. ${ }^{5}$ Pubhic choice theory posits that pohitical interest groups are much more likely to arise when the number of interested parties is sinall because the costs of organizing a large group are much higlier than the costs of forging a small coalition. Furtliermore, the free-rider effects ${ }^{6}$ that plague any organizing campaign multiply as the size of the group in question increases. In short, returns diminish in scale as the number of constituents in an interest group grows. ${ }^{7}$

A simphistic apphication of public choice theory would predict that the dairy lobby could never have been created, due to its sheer size. That lobby represented approximately five million dairy farmers and thousands of factory owners and imddlemen. The costs and free-rider effects of organizing this massive group into a cohesive pohtical force would seem prohibitive. Yet such a lobby was indeed created at the dawn of the special interest state in this country. How was this developinent possible?

This Article explams the creation of the dairy lobby by examining

4. For introductions to public choice theory see I. MCLEAN, PuBLIC CHOICE: AN introduction (1987); D. Mueller, Public Choice (1979).

Mueller defines public choice as "the economic study of nonmarket decisioninaking, or sinply the application of economics to political science." D. MUELlER, supra, at 1; see also Brennan \& Buchanan, Is Public Choice Immoral? The Case for the "Nobel" Lie, 74 VA. L. REv. 179, 179 (1988) ("the application of the theoretical method and techniques of nodern economics to the study of political processes"); Tollison, Public Choice and Legislation, 74 VA. L. REv. 339, 339 (1988) ("economic theory of legislation"); J. Macey, Public Choice: The Theory of the Firm and the Theory of Market Exchange (1988) (unpublished manuscript) ("the application of game theory and microeconomic analysis to the production of law by legislatures, regulatory agencies and courts").

5. In the words of Robert $D$. Tollison, a leading pubhic choice theorist:

$A$ basic principle as well as a basic conundrum underlies the demand for legislation. The principle is that groups who can organize for less than one dollar in order to obtain one dollar of benefits from legislation will be the effective demanders of laws. The conundrum is that economists have little idea of how successful, cost-effective interest groups are forned. That is, how do groups overcome free rider problems and organize for collective action so as to be able to seek one dollar for less than one dollar? The plain truth is that economists know very hittle about the dynamics of group formation and action.

Tollison, supra note 4 , at $341-42$ (footnote omitted).

6. A frce rider is someone who takes advantage of the beneficial activities of others but who does not contribute her fair share to the cost of these activities. A standard example is the sailor at sca who navigates with the help of a lighthouse on shore, the upkeep of which is paid by others. For exposition, see D. MUELlER, supra note 4, at 14-18.

7. For accounts of the economic theory of groups, see M. OLson, THE LogIC OF Collective ACTION: Public GoOds AND THE TheORY OF Groups 53-65 (1965); Stigler, Free Riders and Collective Action: An Appendix to Theories of Economic Regulation, 5 BELL J. ECON. \& MGMT. ScI. 359 (1974); Stigler, The Theory of Economic Regulation, 2 BELL J. EcoN. \& MGMT. SCI. 3 (1971). 
its origins. It theorizes that the dairy industry drew on a preexisting structure of state, regional, and national organizations when it finally entered pohtics. These institutions, originally established to combat certain industry economic problems, enabled dairy leaders to overcome the organizational and free-rider costs that otherwise might have doomed their campaign. This pattern explaims a seeming anomaly, which has perplexed public choice theorists.

A second issue in public choice theory highlighted in this study is how the two basic structural principles of American government-federalism and separation of powers-affect the growth and efficacy of special political interests. This Article posits that, in the case of the inargarine controversy, federahism benefited the dairy industry, while separation of powers hindered it.

The existence of a federal system benefited the dairy lobby because the industry could initiate campaigns for state legislation, where freerider and organization costs were low relative to national pohitics. Legislation could easily be obtained in states with powerful dairy constituencies, providing inipetus for the enactınent of similar legislation in other states. The industry could use the states as "laboratories"-not in Brandeis' positive sense of controlled environments for the development of socially beneficial legislation, ${ }^{8}$ but as experimental settings for the creation of anticompetitive statutes designed to serve narrow special interests.

Once state legislative campaigns were underway, the industry could marshal its resources to obtain federal legislation. State statutes provided models for such federal action. Even setbacks in the dairy industry's campaign at the state level, such as unfavorable judicial rulings, could stinulate lobbying at the federal level. Federal legislation provided a body of protections that overlapped and supplemented the state statutes and held the proinise of eliminating margarine manufacture entirely. If the federal law proved madequate for any reason, the industry could launch a new state-level campaign.

To be sure, federahism did not wholly benefit the dairy industry, because the resources necessary to achieve protection at two levels were potentially greater than those required in a unitary system, and because certain states could serve as havens for margarine manufacturers. On the whole, lowever, federalism facilitated the growth of the special interest state.

Separation of powers, on the other hand, tended to hinder the dairy industry's campaign. To achieve its goal of eliminating coinpetition from

8. See New State Ice Co. v. Liebmann, 285 U.S. 262, 310-11 (1932) (Brandeis, J., dissenting) ("It is one of the happy incidents of the federal system that a single courageous State may, if its citizens choose, serve as a laboratory; and try novel social and economic experiments without risk to the rest of the country."). 
margarine, the industry needed the active cooperation of all three branches of government at both the state and federal levels. Merely enacting legislation was not enough, because legislation needed enforceinent to have effect. In fact, the dairy imdustry encountered resistance froin both the judicial and the executive branches of government in its campaign. Prosecutors failed to enforce the antimargarine laws with any vigor. Even when prosecutors brought enforcement actions, courts often threw thein out on technical or constitutional grounds.

The effect of separation of powers is not entirely clearcut, because the splintering of authority among three branches allowed the dairy industry to focus its organizational resources on the government ann in which the industry was likely to have the most influence-the legislature, where five million votes carried significant force. In a unitary systein, the dairy industry could not have concentrated its fire in this fashion. Nevertheless, the effect of separation of powers generally inhibited the development of the special interest state.

This Article highlights a third aspect of public choice theory: the question of how econormic conditions in an industry affect an interest group's readiness to lobby for protective legislation. In the case of the dairy industry, it appears that political activity increased in times of adverse economic conditions. Dairy lobbying was more intense when butter prices were low and less intense when butter prices were higheven though low butter prices also meant low inargarine sales because inargarine is a substitute for butter. Why an imdustry's anticompetitive activity should be inore intense in times of economic downturn than in prosperous times is something of a puzzle. Enhanced lobbying in times of downturn might have reflected either reduced fears of new entry into the industry (which would otherwise dissipate the benefits derived from lobbying), or dairy farmers' willingness to pay inore to protect a benefit they had than to purchase a benefit that they did not have. ${ }^{9}$

These observations about the growth of large group lobbies, the effects of government structure, and the relevance of economic conditions inay have validity across a range of industries and time periods. This Article, however, focuses on a single industry during a linnited period. Whether the effects posited here exist elsewhere inust await further research.

Part I of this Article describes the origins of the dairy lobby by exaniming the structure of the industry, the growth of factory dairying, and the establishnient of precursors to the dairy lobby in the form of private associations. It then examines the origin of the margarine indus-

9. See Miller, supra note 3, at 426-27 (1987) (discussing the correlation between economic conditions and the dairy industry's campaign against filled milk). 
try and compares the resources available to the dairy and margarine industries at the outset of the pohtical struggle. Part II discusses the dairy industry's early state campaigns and describes the first antimargarine laws. Part III examines the industry's federal campaign that culminated in the Oleomargarine Act of 1886. The Article concludes by examining the antimargarine campaign from the perspective of public choice theory, relating the controversy to some of the broader themes outlined above.

\section{I}

\section{ORIGINS OF THE BUTTER LOBBY}

The dairy mdustry in the early 1870 s showed no indication that, in less than two decades, it would become one of the nation's most potent political lobbies. To be sure, dairy farıners represented a huge potential voting bloc. They were, however, almost entirely disorgamized. No single fariner had an interest $m$ organizing the industry to reduce price fluctuations or develop markets. The free-rider problems that plagne any attempt to organize an interest group were especially severe in the case of the dairy industry. ${ }^{10}$

Moreover, the establishment of an industry lobby had little precedent in either the farming sector or elsewhere in the economy. No federal programs for farmers existed, ${ }^{11}$ nor were there any significant state programs. Dairy farnners believed more in the virtues of sound management and hard work than in salvation through goverument intervention. ${ }^{12}$ Althougli the dairy farmer, like other American agriculturalists, was swept up by the granger crusade of the $1870 \mathrm{~s},{ }^{13}$ the granger movement then focused on broad questions of national policy and did not contemplate organizing dairy farmers into an interest group capable of forcing its special agenda on the nation's political institutions. Nevertheless, within hittle more than a decade the industry had become a powerful and organized special interest lobby. How the lobby evolved is a question of some historical interest. Its answer may shed light on the United

10. For a classic discussion of how free-rider problems can interfere with effective political organization, see M. OLSON, supra note 7.

11. In contrast, today's farm lobby recently obtained the most costly federal farm subsidies in history during a period of overall retrenchment in government spending. See Schneider, Cost of Farm Law Might be Double Original Estimate, N.Y. Times, July 22, 1986, at 1, col. 4 (cost of new farm legislation might reach $\$ 35$ billion in fiscal year 1986).

12. See J. Williams, The EXPANSION OF RURAL LIFE 10-11 (1926) (discussing "sentiment of liberty" among American farmers in 1874, which included a "sentiment of eeonomic independence" and a "sentiment for freedom from political regulation, an attitude of free enterprise"). Leaders of the dairy industry preached "an austere discipline of technical and intellectual fitness for a competitive universe in which the only sure token of grace was 'extra' prices." E. LAMPARD, supra note 2 , at 340 .

13. See E. LAMPARD, supra note 2, at 338-39. 
States' transformation into a special interest state durmg the last part of the nineteenth century.

\section{A. Structure of the Dairy Industry}

Profound technological and economic changes in the 1870s and 1880 s transformed dairying from a cottage industry into a sophisticated, industrialized area of commerce. The industrialization of American dairying, nnoreover, facilitated the creation of a national political lobby when margarine threatened to replace butter as a staple of the national diet.

\section{Dairy Farming in 1873}

By the time commercial production of margarine started in the United States in $1873,{ }^{14}$ dairy farming was already one of the largest doniestic industries. As many as five million farmers owned at least one milk cow during this period. ${ }^{15}$

Unlike other large industries such as the capital-intensive mills and railroads, dairying was still an industry of sinall producers. ${ }^{16}$ Probably a majority of dairy farmers kept a cow to supply personal needs. They sold milk on the market mostly during the peak production period in the sprimg and early summer, if at all. ${ }^{17}$

Dairy products were almost wholly processed on the farm. The fariner sold a portion of the raw milk he produced and converted the rest into butter or cheese, sending it to market in stone jars, soap and candle boxes, tobacco and candy pails, and barrels of all sizes. ${ }^{18}$ The quality of the dairy products depended on the skill of the individual farmer. ${ }^{19}$

Dairy farns were spread out over every state and territory during this period. This wide geographic dispersion of American dairying was due, in part, to the ecological flexibility of the nilk cow, able to survive in all sorts of climates and on various kinds of feed. The lack of centralization also reflected the technological difficulties of brimging fluid milk to markets. A notoriously perishable commodity, fluid milk could sour or,

14. E. W1EST, supra note 2, at 234. This date is only an estimate; the actual point at which commercial margarine production started in the United States is not precisely known. S. RIEPMA, supra note 2, at 110 .

15. See J. Schlebecker, A History of AMERICAN DAIRYINg 4 (1967); Testimony Taken Before the Senate Comm. on Agriculture and Forestry in Regard to the Manufacture and Sale of Imitation Dairy Products, 49th Cong., 1st Sess. 2 (1886) [hereinafter 1886 Hearings] (statement of Joseph H. Reall, President of the American Agricultural and Dairy Association).

16. See U.S. Dep't of Justice, Milk Marketing: A Report to the Task Force on ANTITRUST IMMUNITIES 19 (1977) [hereinafter JUSTICE REPORT].

17. See id. at 19-20.

18. See 1886 Hearings, supra note 15, at 256 (statement of $\mathrm{H}$.W. Henshaw).

19. See E. Guthrie, The Book of Butter: A Text on the Nature, Manufacture and Marketing of the Product 188 (1923). 
worse, become infected with disease if not consumed within a few days after production. With refrigeration still in its infancy, pasteurization decades $\mathrm{m}$ the future, ${ }^{20}$ and relatively primitive transportation systems beyond the railroads' path, milk had to be produced very close to its markets. ${ }^{21}$

Dairy farming was not uinformly distributed throughout the country, however. A vast dairy belt about 150 miles wide, extending from New England westward for about 1800 miles, produced most of the nation's milk, cheese, and butter. ${ }^{22}$ New York led the nation in butter production by far, followed by Pennsylvania, Ohio, Illinois, Iowa, Michigan, Wisconsm, and Minnesota. ${ }^{23}$ The fastest growing butter producing states were Iowa, Wisconsin, and Minnesota, where farmers were turning from wheat production to the tending of milk cows. ${ }^{24}$ Southern states were relatively weak dairy producers.

\section{Growth of Factory Dairying}

In 1873 the dairy industry experienced the first stages of a profound technological change that would revolutionize American dairying: the growth of the factory system for processing milk into cheese and butter.

The first dramatic shift in dairy technology occurred with the production of factory cheese after the Civil War. Factory cheese had numerous advantages over farm cheese. It generally had a higher quality because expertise in cheese making could be concentrated in the factory. ${ }^{25}$ The factory could develop more effective inarketing methods ${ }^{26}$ and could produce cheese in quantities sufficient for sale in national and foreign markets. Cheese factories sprang up across the dairy states during the $1860 \mathrm{~s}^{27}$ by $1899,94.5 \%$ of the nation's cheese was produced in factories. ${ }^{28}$

The industriahization of butter production lagged about a decade behind that of cheese. Initially, the process of making butter in factories (known as "creameries") differed little from the process on the farm. Compared to farm butter production, creameries earned only relatively minor returns to capital. ${ }^{29}$ Thus, creameries existed exclusively as

20. See JUSTICE REPORT, supra note 16 , at 20-21.

21. Id. at 19.

22. 1886 Hearings, supra note 15 , at 3 (remarks of L.I. Seaman).

23. See E. WIEST, supra note 2, at 78 (figures for 1870).

24. See 1886 Hearings, supra note 15, at 4 (Minnesota); E. LAMPARD, supra note 2, at 47-56 (Wisconsin); E. WIEST, supra note 2, at 78 .

25. E. LAMPARD, supra note 2, at 94.

26. See id. at $97-98$.

27. See id. at $94-96$.

28. See E. WIEST, supra note 2 , at 11-13.

29. E. LAMPARD, supra note 2, at 204; E. WIEST, supra note 2, at 40 . Perhaps for this reason, 
adjuncts of cheese-manufacturing plants. ${ }^{30}$

In 1878, however, the mvention of the centrifugal cream separator triggered a revolution in butter making. ${ }^{31}$ The centrifugal separator proved much more efficient at removing the butterfat from milk than the older method of gravity separation. ${ }^{32}$ Because centrifugal separators required a substantial capital investment and could process milk in bulk, they were suitable only for factory use. ${ }^{33}$ Butter produced in factories ("creamery butter") quickly gamed a reputation as having a better taste and a more consistent quality than farm butter ${ }^{34}$-comiotations that attach to the term "creamery butter" even today.

The relative market prices of creamery and farm butter reflected the strong consumer preference for the former. In 1878, Wisconsin creamery butter sold for 38 to $40 \AA$ per pound compared with only about $13 థ$ per pound for farm butter. ${ }^{35}$

These technological and market developments facilitated an explosive rise in creamery manufacture of butter. ${ }^{36}$ Virtually nonexistent in 1869 , Wisconsin's creamery butter production rose to 489,000 pounds in $1879,14,060,000$ pounds im $1889,61,814,000$ pounds in 1899 , and $103,885,000$ pounds im $1909 .{ }^{37}$ Nationwide, factory butter constituted an insignificant percentage of total butter production in 1870 . It rose to $3.6 \% \mathrm{~m} 1880,14.9 \% \mathrm{~m} 1890$, and $28.2 \% \mathrm{im} 1900 .^{38}$

\section{B. Precursors of the Dairy Lobby}

Dairymg's factory system stimulated the establishment of formal and informal organizations that would eventually serve as building blocks in the creation of a national lobby. Although these groups took a variety of forms and represented differing imterests, they all served the goal of miproving and expanding dairy markets. The most miportant groups were (1) factory owners, (2) producer associations, (3) boards of trade and produce exchanges, and (4) producer and dealer cartels.

creameries were relatively small throughout the nineteenth century. See E. GuTHRIE, supra note 19, at 4.

30. E. LAMPARD, supra note 2, at 110; see E. WIEsT, supra note 2, at 20.

31. See E. GuTHRIE, supra note 19, at 57; E. LAMPARD, supra note 2, at 204-08.

32. See E. GuTHRie, supra note 19, at 54-55; W. PAEST, supra note 2, at 14-15.

33. See J. SCHLEBECKER, supra note 15, at 25-26; E. W1EST, supra note 2, at 40 . The creamery's advantages in separation technology were reduced a few years later by the introduction of hand separators suitable for use on the farm. See E. GUTHRIE, supra note 19, at 65; E. WIEST, supra note 2 , at 28-29.

34. See E. GUTHRIE, supra note 19, at 189; E. WIEST, supra note 2, at 16; 1886 Hearings, supra note 15 , at 4 (remarks of L.I. Seaman).

35. E. LAMPARD, supra note 2, at 111.

36. See E. WIEST, supra note 2 , at 39 (tying growth of factory system to the introduction of power and hand separators, extension of railroad service, and superior quality of creamery butter).

37. E. LAMPARD, supra note 2, app. at 453.

38. See E. WIEST, supra note 2 , at 38. 


\section{Factory Owners}

With the growth of factory-produced cheese and butter, a new figure assuined a leading role in the politics of dairying-the factory dairyman. As entrepreneurs, factory dairymen set up butter and cheese factories to exploit the profit opportumities introduced by the new dairying technology. Although they professed solidarity with dairy farmers and swore allegiance to the ideals of animal husbandry, factory dairyinen were inore manufacturers and businessmen than farmers. While inany factory owners maintained herds of milk cows in the early days of factory dairying, their interest in milk production gradually became secondary to their manufacturing businesses. ${ }^{39}$

The interests of factory owners and dairy farmers conflicted in certain respects. Factory owners mointored the operations of their suppliers to improve product quality. They explored new means of production and constantly encouraged farners to improve operations-a call that many farmers strongly resisted. ${ }^{40}$ As purchasers of the dairy fariner's product, they inevitably bickered over terms such as price, quality, and risk. ${ }^{41}$ Moreover, farners who inanufactured their own butter or cheese competed directly with factory owners.

Despite these tensions, factory dairymen were well-qualified for the role of industry champions. First, their interests coincided with those of dairy farmers on issues affecting the industry generally. Both groups, for example, wanted to stave off competition from nondairy products. Farmers could trust factory dairymen to represent them in a cainpaign focused on ehminating competition from butterfat substitutes.

Second, factory owners had stronger incentives to organize the industry than did farmers because margarme threatened them more than it did farmers. Factory owners wanted to protect their capital investments, which were both larger and less diversified than the investinents of dairy farmers. ${ }^{42}$ The dairy farmer could market raw milk in fluid form or for cheese; if milk production became unprofitable he could send his cows to the stockyards and convert land to other productive use. In contrast, the creamery owner faced ruin if butter making becaine unprofitable. In addition, the relatively small number of factory owners alleviated the pervasive free-rider problems that hampered the organization of an undifferentiated mass of small dairy producers.

39. See E. LAMPARD, supra note 2, at 101-05 (describing the importance of factory owners to the growth of Wisconsin dairying).

40. Id. at $97-99,105$.

41. See id. at $98-99$.

42. Factory dairymen needed to purchase a fairly wide variety of equipment that could not realistieally be turned to other uses. See E. GUTHRIE, supra note 19, at 54-83 (separators), 123-26 (power churns), 155-59 (cutters), 183-85 (cold storage facilities). 
Third, factory owners generally possessed intellectual and organizational abilities well-suited for industry leaders. ${ }^{43}$ Aware of the rapid growth of industry and science in the United States and of the far-reaching consequences these trends portended for dairying, the owners participated in wholesale inarkets for cheese and butter that were national and even international in scope. Involveinent in these inarkets gave factory dairymen a broad overview of the dairy industry's probleins and a network of contacts with dairy leaders in other states.

These qualifications enabled factory owners to spearhead the industry's early campaigns agamst margarine. They masterminded the industry's overall strategy and directed its day-to-day operations. This relatively cohesive cohort of specially qualified and motivated leaders helped crystallize the industry into a powerful lobby in the legislative battle for protection aganist margarine.

\section{Dairy Associations}

A variety of county, state, and national dairy associations represented a second important precursor to the national dairy lobby. These associations atteinpted to expand regional inarkets for dairy products. They responded to two important market needs: 1) coping with a perceived problem of "overproduction"; and 2) policing against opportumistic behavior by members.

\section{a. Overproduction}

Dairy farming, like other areas of agriculture, was often said to suffer from "overproduction." ${ }^{44}$ Repeated constantly at industry ineetings, the bugbear of overproduction haunted dairy farners. Yet dairymen seldom explained exactly what they meant by the term. It implied that simply too inuch milk was on the market. Presumably, the concern was based on the following postulate: In a systein of factory dairying, with interhinked geographic markets, any exogenously caused rise in the supply of dairy products would drive prices down. Faced with lower prices, dairy farners would have to step up production to break even. Their efforts would be futile, however, because the more they produced, the inore prices would fall and thus the less they earned for their labors.

This concept of overproduction makes hittle economic sense. Prices in dairy markets are functions of supply and deinand. An unexpected increase im supply or decrease in demand will cause prices to fall, perhaps even to the point where the farner suffers an outright loss. This situation will not last, however, because some farmers will leave the inarket. Sup-

43. E. LAMPARD, supra note 2, at 104-46.

44. See id. at 121. 
ply will contract, driving prices back to levels at which farmers can earn competitive returns on their capital investinent and labor. Under traditional market theory, a sustained condition of overproduction in an unregulated coinpetitive market is impossible. ${ }^{45}$

As applied to conditions in dairying in the late nineteenth century, references to overproduction were more accurately complaints about the industry's lack of barriers to entry ${ }^{46}$ Low butter prices cut into farmers' profits and reduced the value of their herds. During these periods farmers were indeed overproducing, in the sense that the industry no doubt operated on low profit inargins. But low prices in one period must have been balanced by high prices in another, when farmers earned good profits on their investinent in farm and herd. Indeed, despite the variability in butter prices, the total number of dairy cows increased in linear fashion over the entire period, growing froin approximately ten inillion cows in 1870 to approximately fourteen inillion cows in $1886 .{ }^{47}$ The increase in the number of cows suggests that dairy farming was not unprofitable relative to other occupations during this period. Thus, it seems apparent that references to "overproduction" were often disguised complaints about the lack of protection against coinpetition. ${ }^{48}$

The problem of overproduction (or lack of supercoinpetitive profits) could be mitigated either by reducing output or by increasing deinand. Output could be reduced by forming a cartel. The free-rider and organizational costs of cartelizing the butter industry as a whole, however, were probably prohibitive, given thousands of dairy factories shipping butter

45. See J. Doll, V. RHOdES \& J. West, ECONOMICS OF Agricultural Production, MARKETS AND POLICY 263-82 (1968).

46. In the twentieth century, by contrast, "overproduction" typically describes the surplus that can be expected to accompany government price support programs for farm products. See generally THE OVERPROdUction TRAP IN U.S. AGRICULTURE (G. Johnson \& R. Ruance eds. 1972).

47. NUMBER OF MILK COWS IN U.S. 1870-1886

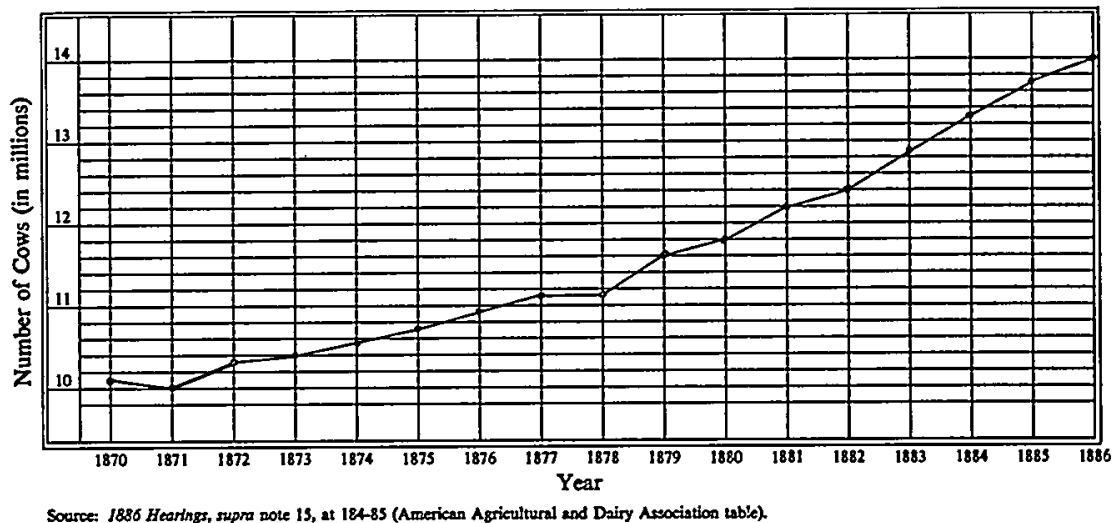

48. See 1886 Hearings, supra note 15, at 25 (statement of W.P. Richardson) (complaining that competition from other milk producers had disrupted a producers' cartel). 
into geographically extended markets. ${ }^{49}$ Increasing demand represented a more feasible alternative because butter produced in areas with good reputations sold for more than butter from other areas. ${ }^{50} \mathrm{~A}$ region's farmers and factory owners could raise prices by increasing the reputation of their product relative to products from other regions. Although the benefits of increased demand would partially dissipate over time through new entry, supercompetitive profits were possible in the short term. Even in the long run, profits were unlikely to be completely dissipated because the potential for cartels was stronger in narrowly segmented markets.

\section{b. Opportunism}

A basic technological limitation in dairying rested in the difficulty of assessing the quality of dairy products on simple inspection. ${ }^{51}$ Butterfat content and resistance to spoilage primcipally determined the value of dairy products. Neither quality could be measured directly. No simple measure of butterfat content existed until the introduction of the Babcock butterfat test in $1890 . .^{52}$ Grading of milk and cream did not become commonplace until early in the twentieth century..$^{53}$ As to perishability, almost anyone could detect spoiled cheese, rancid butter, or sour milk, but it was virtually impossible to ascertain how long a fresh dairy product would remain fresh. Middlemen, retailers, and exporters assumed spoilage risk while the products rested in their control. ${ }^{54}$

These technological shortcomings created a classic form of market failure which George A. Akerlof terms the "market for lemons." 55 The difficulty in directly measuring the quality of dairy products subjected dairy inarkets to severe informational asyminetries in which the seller knew more about the quality of the product than did the buyer. In such conditions, buyers must rely on some statistic as a proxy for qualities

49. See generally G. StiGler, The Theory of Price 230-37 (1966).

50. See infra notes 63-64 and accompanying text.

51. See E. GuTHRIE, supra note 19 , at 84-87.

52. See E. LAMPARD, supra note 2, at 197-202; J. ScHLEBECKER, supra note 15, at 31. Dairy leaders unanimously agreed on the revolutionary effects of the Babcock test. In the words of William Dempster Hoard, the test came "none too soon to enable some dairymen to correct certain practices of which they had been guilty and which, if continued, would have barred them from passing through the portals where Saint Peter stands as the faithful sentinel." G. RANKIN, supra note 1 , at 161 .

53. See E. GUTHRIE, supra note 19 , at 86 (cream first graded in 1905).

54. The spoilage problem became particularly acute in the export market for cheese, where domestic manufacturers had taken to "filling" cheese made from skim milk with various animal or vegetable fats. Filled cheese, which could not readily be distinguished from ordinary cheese, spoiled much more rapidly than cheese made from whole milk, and often turned during the voyage to European markets. See E. LAMPARD, supra note 2, at 245-48.

55. Akerlof, The Market for "Lemons": Quality Uncertainty and the Market Mechanism, 84 Q.J. ECON. 488 (1970). 
that cannot be directly measured. The nature of that statistic in the dairy industry depended on the market in which the dairy product was sold. In raw milk supply markets, the volume of milk supplied by the farmer served as the operative statistic. ${ }^{56}$ In wholesale and retail markets for processed dairy products, the statistics were weight, variety, and geographic origin. Hard cheese might command a higher price than soft; Wisconsm butter might sell for more than Iowa butter, and so on. ${ }^{57}$

But the use of statistics in place of direct quality measures invites sellers to behave opportunistically, which creates the market for lemons. Akerlof describes the problem as follows:

There are many markets in which buyers use some market statistic to judge the quality of prospective purchases. In this case there is incentive for sellers to market poor quality merchandise, simce the returns for good quahity accrue mainly to the entire group whose statistic is affected rather than to the individual seller. As a result, there tends to be a reduction in the average quality of goods and also im the size of the market. ${ }^{58}$

In the dairy imdustry sellers could, and did, behave opportunistically. Farmers, knowing they would be paid on a volume basis, supplied milk that was watered or partly skimmed, fed their cows on inadequate fodder, or simply used inferior animals that produced milk low in butterfat. ${ }^{59}$ Owners of cheese factories, knowing that their product would sell in foreign markets at the same price as all other American cheese of the same type, manufactured cheese out of skim milk laced with vegetable oil. ${ }^{60}$ Butter manufacturers, knowing that their product was sold by weight, churned it with water to produce "overruns"61 and failed to maintain high standards of cleanliness and care. ${ }^{62}$ Middlemen, knowing that the value of processed dairy products depended on geographic location, obtained cheap butter or cheese from one state and passed it off as premium merchandise from another state. ${ }^{63}$ Butter factories contrived to insert the word "Elgin" in their names, hoping consumers would unistakenly associate their product with Elgin butter, widely known as the

56. E. WIEST, supra note 2 , at 25 .

57. See id. at 128-29. Price differentials based on geographic origin were often pronounced. In 1877 , for example, butter from Elgin, Illinois sold for 38 to $40 \uparrow$ per pound, while the best New York butter sold for only 30 to $33 \notin$ per pound. $I d$. at 129 . Butter from other areas sold for even less.

58. Akerlof, supra note 55 , at 488.

59. E. LAMPARD, supra note 2, at 99; M. OKUN, supra note 2, at 192-93; E. WIEST, supra note 2 , at 25 .

60. See Act of June 6, 1896, ch. 337, 29 Stat. 253 (regulation and taxation of filled cheese).

61. E. GUTHRIE, supra note 19, at 217; E. WIEST, supra note 2, at 33-34 (defining "overrun" as the increase of finished butter attributable to water and substances other than fat).

62. See Oleomargarine: Hearings Before the House Comm. on Agriculture, 56th Cong., 1st Sess. 196 (1900) [hereinafter 1900 House Hearings], reprinted in The Oleomargarine Bill: Hearings on H.R. 3717 Before the Senate Comm. on Agriculture and Forestry, 56th Cong., 2d Sess. 703 (1901).

63. See id. 
nation's finest. ${ }^{64}$ Retailers sold margarine and "renovated" butter to customers at premium butter prices. ${ }^{65}$ The list could be extended. ${ }^{66}$

Although informational asymmetries existed in the dairy industry prior to 1876 , the growth of industrialization in dairying severely aggravated the leinons problem. In dairying's days as a cottage industry, buyers often obtained their butter, milk, and cheese from a farmer whose reputation depended on the quality of his product. ${ }^{67}$ Knowing that buyers would go elsewhere if his products turned out to be inferior, the farmer supplied goods of rehiable quality. In contrast, the factory system separated buyers and sellers by several layers of middlemen such as wholesalers, jobbers, and retailers. ${ }^{68}$ Moreover, goods of different suppliers were consolidated into common pools and sold as fungible umits. Producers pooled milk for sale to factories; factories sold cheese and butter into markets where price was determined by the factory's location; and dairymen across the country operated in a world inarket where the price for American butter and cheese depended on its general reputation for quality. These developments meant that the price a supplier could obtain no longer wholly depended on the quality of his product.

Accordimgly, the problem of opportunistic behavior in dairy markets became acute after the advent of factory dairying. The lemons markets that developed posed a threat to the industry at all levels of production and distribution. As Akerlof points out, a lemons market is a market in breakdown. ${ }^{69}$ Because buyers expect that sellers will behave opportumistically, the amount they are willing to pay drops below the amount demanded by sellers of higher quality goods. Thus, inferior goods tend to drive superior ones off the market in a peculiar manifestation of Gresham's Law. ${ }^{70}$ Because social and private returns differ, the consequence is a deadweight social loss. ${ }^{71}$

64. See E. GUTHRIE, supra note 19, at 202.

65. On renovated butter, see E. GUTHRIE, supra note 19, at 216-18; E. WIEST, supra note 2, at 229-34.

66. For example, farmers who delivered witole milk to creameries received a pro rata share of a common pool of skim milk which they typically fed to livestock. This skim milk was often of degraded or inferior quality and was sometimes infected with tuberculosis or other diseases. See E. WIEST, supra note 2, at 28, 35-36. The introduction of a separator suitable for farm use in the 1890 s mitigated this particular problem. See id. at 35-36; T. PIRTLE, HisTORY OF THE DAIRY INDUSTRY 82-83 (1926).

67. See JUSTICE REPORT, supra note 16, at 19; E. WIEST, supra note 2, at 159.

68. See E. WIEST, supra note 2, at 159.

69. See Akerlof, supra notc 55, at 488-89.

70. Gresham's Law states that bad money tends to drive out good money in an economy where both are in use. See id. at 489. As Akerlof observes, the analogy to Gresham's Law is not precise because money users know which is bad money and which is good, whereas purchasers of goods subject to severe quality uncertainty are not able to distinguish between good and poor quality commodities. Id. at 490.

71. Id. at 488. 


\section{c. The Growth of Dairy Associations}

Factory dairymen and other dairy industry leaders responded to these two probleins of dairying-overproduction and informational asyinmetry - by organizing the industry on a county-wide and eventually state-wide basis. ${ }^{72}$ Small groups of producers and factory inen formed the first dairy associations in order to enhance the prestige of dairy products from their region. These associations aimed to mitigate the leinons problenn and increase demand by establishing a reputation for quality in dairy products produced by the associations' members. Dairy association activities typically included entering the products of their region in fairs and expositions, encouraging the use of modern dairying techniques by local farmers, and preventing opportunistic behavior by their members. ${ }^{73}$

Associations developed first at the local level because organizational costs and free-rider effects are lower in sinall groups than in large groups. Once in place, however, these local associations greatly reduced the costs of statewide organization because a state association could be constructed out of the local groups. Accordingly, dairy associations quickly grew to statewide proportions. In 1866, a group of New York cheese makers formed the American Dairymen's Association, which-although purportedly national in scope-essentially operated as a New York organization. ${ }^{74}$ Vermont (the greatest dairy state in inilk produced per square mile) ${ }^{75}$ organized a dairy association in $1869 .{ }^{76}$ Likewise a sniall elite principally concerued with the expansion of the factory interest in their state formed the Wisconsin Dairymen's Association. ${ }^{77}$ In addition to general dairy associations, specialized orgamizations with broad geographic scope sprang up for the purpose of enhancing the value and prestige of particular dairy cow breeds. ${ }^{78}$

These broader associations originally intended to increase domestic consumption of their menibers' products and exploit the possibilities of entering foreign markets. ${ }^{79}$ In other words, the associations helped dairymen maintain supercoinpetitive profits through continuous expansion of markets. State dairy associations also informed dairy farmers

72. See E. LAMPARD, supra note 2, at 124-25 (describing the growth of small local groups into Wisconsin dairy associations).

73. See, e.g., E. GUTHRIE, supra note 19, at 189 (describing the influence of dairy associations in developing grading systems for butter).

74. E. LAMPARD, supra note 2, at 122.

75. E. WIEST, supra note 2 , at 79.

76. Id. at 101.

77. E. LAMPARD, supra note 2, at 104.

78. See, e.g., 1886 Hearings, supra note 15, at 1 (mentioning the Holstein Breeders Association).

79. See E. LAMPARD, supra note 2, at 122-25; 128-29. 
about market conditions and new developments in dairy science through association gatlierings, county fairs, and publications. These educational activities improved the quality of dairy products produced within the states. ${ }^{80}$

Various dairy newspapers serving different parts of the country were loosely affiliated with the state dairy associations. ${ }^{81}$ The most influential periodical in Wisconsin was the Jefferson County Union, publislied by Williain D. Hoard, a prominent spokesman for the factory interests, later Governor of Wisconsin, and ultimately leader of the industry's national campaign agamst margarine in 1900-1902. ${ }^{82}$ The Rural New Yorker exerted similar influence in New York and New Jersey. ${ }^{83}$

The activities of the state dairy associations were not exphicitly political at first, except for a few isolated incidents of petitioning state legislatures for protection against particular, defined evils. ${ }^{84}$ However, organizing the industry into unified groups focused on a cominon end naturally facilitated the exercise of political power; the dairy leaders' goals, moreover, were such that they could be accomphished through legislation.

\section{Boards of Trade and Produce Exchanges}

Boards of trade and dairy produce exchanges made up a third key building block in the national dairy lobby. As the factory system expanded, wholesale inerchants began to play an important role in the distribution of butter and otler products. To facilitate their operations, inerchants organized into boards of trade and produce exclianges such as the New York Mercantile Exchange, tlie Chicago Butter and Egg Board, the Elgin Board of Trade, the Chicago Produce Exchange, and the Baltiinore Produce Exchange. ${ }^{85}$

These bodies facilitated dairy product transactions in extended geographic inarkets by allowing buyers and sellers to convene in a centralized location at which prices could be set quickly and accurately. They defined classes and grades of butter to encourage quality standardiza-

80. See E. WIEST, supra note 2, at 128.

81. See T. PIRTLE, supra note 66 , at $140-41$.

82. Hoard is beatified in G. RANKIN, supra note 1. The Jefferson County Union started publication in 1870. Hoard later established the most influential national journal for the dairy industry, Hoard's Dairyman, which first appeared in 1885. The success of Hoard's Dairyman provides some measure of the growing power of the dairy lobby: its circulation was a mere 700 in 1885 , over 11,000 in 1892 , and nearly 70,000 by 1918 . E. LAMPARD, supra note 2, at 341 .

83. See G. RANKIN, supra note 1, at 204.

84. For example, in 1864 the New York State Cheese Manufacturers' Association obtained a law prohibiting dilution of milk by farmers supplying cheese factories. E. WIEST, supra note 2, at 25 n.2.

85. See E. GUTHRIE, supra note 19 , at 194-95; 1886 Hearings, supra note 15 , at 130. 
tion. ${ }^{86}$ Most initiated imspection programs for grading particular lots of butter. ${ }^{87}$ In addition to grading, inspectors often counseled producers on improving the quality of their products. ${ }^{88}$ By standardizing the product, they widened the geographic scope of dairy markets, mducing other dairy groups to organize at regional and national levels. As preexisting organizations of dairy merchants, boards of trade and produce exchanges readily enlisted in the campaign against margarine.

\section{Cartels}

Cartels of buyers and sellers of fluid milk became a fourth organizational form that contributed to the antiniargarine campaign. Because of its extreme perishability, fluid milk could be marketed only in linnited geographic areas or in areas served by efficient rail transportation. This natural market limitation reduced the number of participants in inilk markets and thereby facilitated cartehization. Both buyers' and sellers' cartels formed during this period. ${ }^{89}$ Around 1880, producers began to band together into regional associations to control prices paid by dealers. ${ }^{90}$ The president of the Orange County Milk Producers' Association of New York described how organizing into a county-wide association gave the farmers enlianced bargaining power in the milk market:

[F]or a number of years prior to the year 1883 business had been depressed, from the fact that the men with whom the farmers were dealmg were sharp and unscrupulous im their business ways and had succeeded in reducing the prices of milk to a figure that made the business unprofitable. In 1882 we formed an organization of the producers of milk for the New York market, an organization of farmers in that particular section, for the purpose of mutual protection. We succeeded in 1883 in forming a strong association of some eight hundred members, and became an incorporated body, and succeeded by the withholding of milk, or by what was known at that time as the Orange County Milk War, in mcreasing the price of milk to the farmers of our county so that they received in the years 1883 and 1884 nearly a million dollars more for their product than they had received prior to that time . ... ${ }^{91}$

Purchasers of fluid milk also established their own buyers' cartels. In response to the growth of the Orange County Milk Producers' Association, the creaineries and larger milk dealers in the New York City milkshed organized the New York Milk Exchange Limited, which attempted to control the industry through overt price fixing. The bylaws of the

86. E. GUTHRIE, supra note 19 , at 195 .

87. Id. at $198-200$.

88. Id. at 200 .

89. See 1886 Hearings, supra note 15, at 25 (statement of W.P. Richardson, President, Orangc County Milk Producers' Association).

90. See M. OKun, supra note 2, at 199.

91. 1886 Hearings, supra note 15, at 25 (statement of W.P. Richardson). 
exchange required members to adhere to specified rates paid to dealers and charged to consumers. ${ }^{92}$

Producer and purchaser associations thus organized the dairy industry into groups that could easily become politically active when the need arose. Although the producer associations' goals were imitially adverse to those of factory owners and milk dealers, tliere was no reason why these different interests could not cooperate on matters of mutual concern. Margarime, because it threatened the interests of dairy farmers as well as factory owners, provided an obvious rallying point for the whole imdustry.

$$
* * *
$$

The factory system created a high degree of economic interdependence among dairymen, stimulating the formation of various associations and groups at different geographical levels. It took but a small step to turn these groups to political action once the appropriate issue arose. Accordingly, when the leaders of the dairy industry decided to counter the margarime threat through political action, they did not face the daunting task of organizmg five milkon farmers and a substantial number of middlemen, retailers, and factory owners from scratch. Rather, the dairy lobby crystallized out of powerful but previously nonpolitical bodies which themselves had been organized in response to the factory system in dairymg.

\section{Origins of the Margarine Industry}

Altlougli the dairy imdustry established a base for organized political action by the mid-1870s, only an external threat finally galvanized the imdustry's leaders into enterimg politics in earnest. That threat arrived on the scene in the form of margarine, an unanticipated technological development that irrevocably altered the political orgamization of the dairy industry.

A French chemist, Hippolyte Mège-Mouries, invented margarine sometime in the late 1860s. He made the product froin oleo (refined caul fat of beef) churned witl milk, salt and a few other ingredients. ${ }^{93}$ Mistakenly believing that his invention contained inargaric acid, MègeMouries called it "oleo-inargarine," a name that quickly achieved univer-

92. See M. OKun, supra note 2 , at 200 .

93. S. RIEPMA, supra note 2, at 7-8; M. SchwITZER, MARgARINE AND OTHER FOOD FATS: Their History, Production AND USE 60 (1956); K. SNOdGRASS, supra note 2, at 125-26; Van Alphen, Hippolyte Mège Mouries, in Margarine: AN Economic, Social and ScIENTIfic HISTORY 1869-1969 5, 6-7 (J. Van Stuyvenberg ed. 1969).

Mège-Mouries began his research with the bizarre hypothesis that melting the fatty tissue of cow udders would produce the basic fat material of butter. E. LAMPARD, supra note 2, at 257-58. He was awarded a prize by Napoleon III for developing the best butter substitute. M. SCHWITZER, supra, at 59; K. SNODGRASS, supra note 2, at 125. 
sal acceptance. ${ }^{94}$ The product was a smashing success. When colored with vegetable dye, margarine was a dead ringer for yellow butter. It had a buttery taste, ${ }^{95}$ could be substituted for butter in cooking or as a spread, and had similar qualities of perishability and digestibility. Above all, margarine could be sold at about half the price of butter. ${ }^{96}$

The commercial potential of inargarine immediately becaine apparent. Entrepreneurs around the world eagerly sought to exploit the product. Commercial margarine production in this country began when Mège-Mouries obtained a United States patent on his invention and sold it to the Umited States Dairy Company. ${ }^{97}$ The invention, however, proved impossible to protect; competitors filed over 180 patents in the ensuing years that designed around the Mège-Mouries claim by specifying slightly different procedures for treating the fat or including minor ingredients not contained in the original patent. ${ }^{98}$ Soon margarine producers operated in a number of states, shipping their products nationwide.

Margarine manufacture remained a fairly concentrated industry during this period. Fifteen margarine factories operated in 1880, twelve in 1890 , and only twenty-four by $1900 .{ }^{99}$ Among the first inajor margarine producers were the great Chicago ineat packing firms. ${ }^{100}$ These firms enjoyed important advantages over other producers: ready access to meat fats, an efficient rail transportation systein, centralized facilities for inanufacture and shipinent, and nationwide inarketing networks. The ineat packers enhanced their advantage when they discovered in the 1870s that they could increase quality and lower manufacturing costs by substituting neutral lard (processed hog fat) for some of the oleo oil. ${ }^{101}$ Chicago quickly became an important center of oleomargarine manufacture. ${ }^{102}$

One additional technological development became important to the subsequent politics of margarine: the practice of some inargarine producers to substitute small ainounts of cottonseed oil for some of the oleo or neutral lard. Cottonseed oil was considerably cheaper than these other fats, although it could not be used in quantity because the taste could not be completely neutralized and because the oil adversely affected inarga-

94. S. RIEPMA, supra note 2, at 6-7; K. SNODGRASs, supra note 2 , at 129.

95. See M. OKUN, supra note 2, at 252-53.

96. For a comparison of margarine and butter prices between 1877 and 1886 , see infra notes 117-119 and accompanying text.

97. M. OKUn, supra note 2, at 252; W. PABST, supra note 2, at 19; Note, The Oleomargarine Controversy, supra note 2, at 632 .

98. See W. PABST, supra note 2, at 19.

99. E. LAMPARD, supra note 2, at 258.

100. See K. SNodgrass, supra note 2, at 132-33.

101. See id.; W. PABST, supra note 2, at 20.

102. See W. PABST, supra note 2, at 21 . 
rine's melting qualities. ${ }^{103}$ The use of cottonseed oil, however, gave the Southern cotton states an interest in promoting the margarine business, an interest which later proved pohtically significant in the national struggle over margarine.

\section{Political Resources of the Dairy and Margarine Interests}

As the struggle between butter and margarine began, the two industries enjoyed fundainentally different political resources; these resources dictated each industry's political strategy. The dairy industry's resources favored legislative action, while the resources of the margarine forces favored executive and judicial action (or inaction).

A representative legislature clearly favored the dairy industry for three reasons. First, the industry enjoyed the support of the nation's five inillion dairy farmers who sold on cash markets, coupled with middleinen and factory owners whose livelihoods depended on butter. These voters had a strong personal interest in protecting butter inarkets against competition from inargarine because their capital was not highly diversified. This was especially true of middlemen and factory men who dealt specifically in butter rather than dairy products generally. Second, the various private industry organizations could monitor elected officials and mobilize their constituencies to reward pro-dairy votes and punish promargarine votes. Finally, the presence of dairy farmers in every state allowed the industry to mobilize on a national level, while the relative concentration of dairying in New York, Wisconsin, Pennsylvania, and Vermont gave the industry sufficient power in certain states to overcome local lawmakers' initial resistance to new and unfamiliar legislation.

The margarine industry enjoyed far less direct voting power. In contrast to butter production, margarine production was capital-intensive, with only a few thousand people working directly in that business. Only in Chicago was the direct voting support for margarine manufacturers a significant factor.

Nationally, livestock and cotton interests were aligned with the margarine manufacturers because ineat fats and cottonseed oil were used in inargarine inanufacture. However, their interest in protecting margarine inanufacturers was relatively slight. While livestock owners could profit from margarine, their livelihoods did not depend on it, since margarine added only marginally to the total value of a head of beef or a hog. As to cotton interests, the technological problems of using cottonseed oil in margarine left the value of margarine largely unrealized.

In one sense the margarine interests were allied with the largest voting bloc of all, the general public, since the public undoubtedly benefited

103. See K. SNOdgRASS, supra note 2, at 134-36; E. WiesT, supra note 2, at 221. 
from the availability of a cheap and palatable butter substitute. Immigrants and blue collar workers, who could not otherwise afford to put butter on their tables, were the most obvious beneficiaries. Despite their size, however, these segments of the public were completely unorganized. Thus, while the several million dairy farmers organized into an effective political power group, the many millions of immigrants and blue collar workers almost never participated actively in the controversy.

The dairy industry's advantage in raw voting power was offset somewhat by the margarine industry's greater access to capital. Margarine manufacturers tended to be large corporations with substantial cash incomes. ${ }^{104}$ They could raise the funds necessary to combat the dairy industry's campaign with ease and could treat the expenditures as an ordinary cost of doing business. Firms in the dairy industry tended to be smaller, and therefore enjoyed considerably less access to ready capital. ${ }^{105}$

Moreover, margarine interests suffered less from agency and freerider effects than did the dairy industry. Although the fariner might be willing to write constituent inail or to vote as recommended by dairy leaders, he was much less likely to send hard-earned cash to somebody who might not use it as the farmer wished. Margarine manufacturers, on the other hand, spent their capital themselves, thereby reducing agency costs. Unilateral expenditures by margarine inanufacturers did raise free-rider problems, but the relatively high degree of concentration in the industry mitigated these concerns. ${ }^{106}$ Expenditures by Arinour and Swift, for example, would redound largely to their own benefit because of their large market shares.

At the outset of the battle over margarine, therefore, the two industries possessed different strengths and weaknesses. The next Part describes how the competing industries used these resources in the first skirmishes of the margarine war.

104. For example, Armour \& Co., the great Chicago packing house, was among the biggest margarine manufacturers at the time. See 1886 Hearings, supra note 15, at 102 (statement of George H. Webster); id. at 224-27. The United States Dairy Company was affiliated with the Commercial Manufacturing Company, which was the largest company in the United States, according to one witness at the Senate hearings. See M. OKUN, supra note 2, at 252; 1886 Hearings, supra note 15, at 146 (statement of James H. Seymour). United States Dairy Company was also linked with H.K. and F.B. Thurber \& Co., the nation's largest wholesale grocer. See M. OKUN, supra note 2, at 100, 252.

105. In 1904 , the average value of product per creamery was $\$ 24,000$, compared with $\$ 400,000$ for margarine factories. W. PABST, supra note 2, at 22. Although data are not available for earlier years, the discrepancy was probably larger before 1886. Dairy farms, of course, were even smaller operations than creameries. See supra notes 16-17 and accompanying text.

106. See 1886 Hearings, supra note 15, at 105 (statement of George H. Webster) (noting that there were about thirty margarine producers nationwide); supra notes 99-102 and accompanying text. 
II

\section{The DAIRy INDUSTRY ENTERs Politics}

The dairy industry entered politics in earnest in 1877, when inargarine began to challenge the liegemnon of butter in the nation's diet. The industry's policy was clear from the start: Do everything possible to ensure that margarine did not compete freely with butter.

The butter interests' search for protection hardly seems surprising from the perspective of today's political environment, where special interests routinely vie for governinent favors. In its era, however, the dairy industry's battle against inargarine was unusual. It was among the first national cainpaigns by one domestic industry to enlist the government to crush competition froin another. In a sense, the first shots in the margarine war inark the birth of the modern special interest state.

\section{A. The Initial Dairy Industry Response}

Althougl margarine posed an obvious threat to butter, the dairy interests did not immediately organize effective political opposition to the product. The industry's initial hesitation resulted principally from a belief that margarine did not threaten the factory interests. When margarine first appeared in the United States in 1873, creameries were still in their infancy. Most dairy factories produced only cheese, a product that margarine did not threaten. Those factory owners who had moved into butter production may well have seen margarine as more a blessing than a curse. "Creamery butter" had begun to command a significantly ligher price than farn butter. ${ }^{107}$ If margarine displaced butter at all, it would drive out farm butter, ${ }^{108}$ to the advantage of coinmercial butter producers. Quite possibly, inferior farn butter created soinething of a leinons market that depressed the prices of creamery butter. If inargarine eliminated farm butter, the position of creamery butter could improve. This view of margarine may explain why some industry leaders regarded the product with apparent equanimity during its first years on the market. ${ }^{109}$

In addition, favorable conditions in the dairy industry between 1873 and 1877 assuaged concerns about competition froin inargarine. Dairy farıning had been profitable since the Civil War. Butter prices increased

107. The advantage was pronounced by 1878 and almost certainly existed five years earlier. See E. LAMPARD, supra note 2, at 110-11.

108. See E. WIEST, supra note 2, at 235 (describing competition between oleomargarine and cheaper grades of butter).

109. See E. LAMPARD, supra note 2, at 258. A Wisconsin factory owner declared with apparent pleasure that margarine was "giving better satisfaction than most dairy butter as now made," and predicted that unless dairy (farm) butter improved, margarine would drive it off the market. Id. 
threefold between 1861 and $1866,{ }^{110}$ presumably as a result of wartime shortages. Although prices dropped after 1866, they remained well above their prewar levels. ${ }^{111}$ After 1872, prices began to rise again. The average price of butter in Wisconsin was $18 \mathbb{4}$ per pound in 1873, a major improvement over the $14.6 \$$ per pound of the previous year. ${ }^{12}$ By 1874 , Wisconsin butter had jumped to $21.8 \$$ per pound; and prices remained relatively high through $1877 .{ }^{113}$ Moreover, the number of milk cows increased significantly during this period, with only a slight decline in the average price per cow. ${ }^{114}$ Although high butter prices undoubtedly enhanced margarine sales, ${ }^{115}$ this fact, if observed at all, apparently did not disturb the industry's general sense of well-being. Given the prosperous times, the absence of any significant dairy industry clamor about imitation butter is not surprising.

Industry leaders, however, had sorely underestimated the margarine threat. If unscrupulous dealers could palm farm butter off on consumers as creamery butter, they could do the same with margarine and earn equal or greater profits from their fraud. The lemons problem would be exacerbated, not improved.

The problem of fraudulently representing margarine as butter was well-known by the mid-1870s. Mark Twain's Life on the Mississippi, published in 1874, records the boasts of an early oleomargarine salesman overheard on a Mississippi steamboat:

'Now as to this article,' said [the salesman], 'it's from our house; look at it-smell of it-taste it. Put any test on it you want to. Take

110. Guthrie reports wholesale butter prices of $14.75 \notin$ per pound in 1861 and $44.5 \notin$ per pound in 1866. E. GuTHR1E, supra note 19, at 199.

111. Id.

112. E. LAMPARD, supra note 2, at 455 .

113. Id.

114.

AVerage Value of Milk Cows in the United STates, $1870-1886$

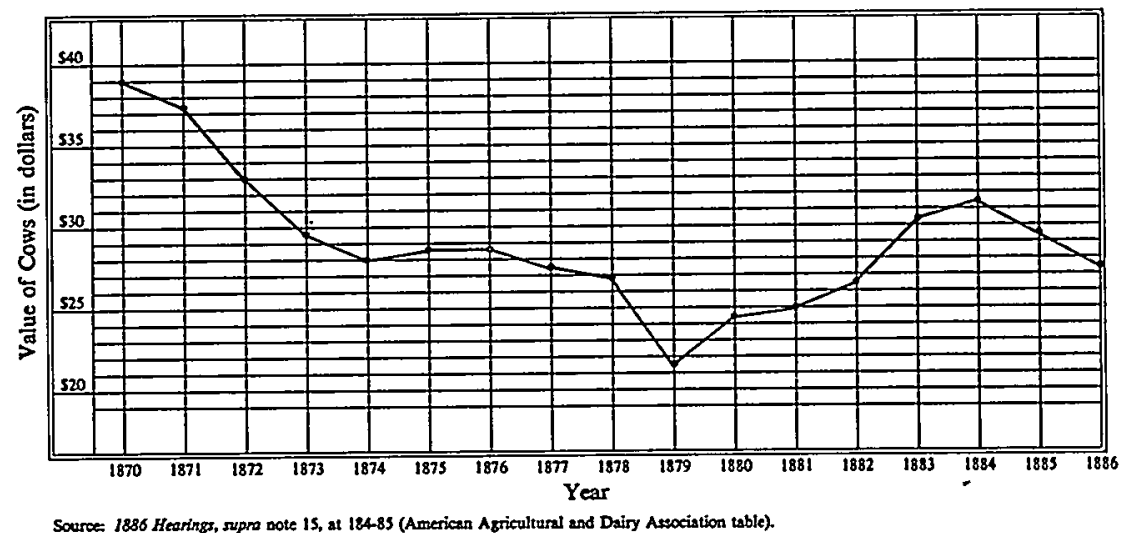

115. For analysis of demand cross-elasticities between margarine and butter, see E. W1EST, supra note 2 , at 206-08. 
your own time-no hurry-make it thorough. There now-what do you say? Butter, ain't it? Not by a thundering sight-it's oleomargarine! Yes, sir, that's what it is-oleomargarine. You can't tell it from butter; by George, an expert can'tl ... We supply most of the boats im the West; there's hardly a pound of butter on one of them. We are crawling right along-jumping right along is the word. We are going to have that entire trade. Yes, and the hotel trade too. You are going to see the day, pretty soon, when you can't find an ounce of butter to bless yourself with, im any hotel in the Mississippi and Ohio valleys, outside of the biggest cities. Why, we are turning out oleomargarine now by the thousands of tons. And we can sell it so dirt-cheap that the whole country has got to take it-can't get around it, you see. Butter don't stand any show-there ain't any chance for competition. Butter's had its day-and from this out, butter goes to the wall., ${ }^{116}$

Twain's report boded ill for the dairy industry, although it would be a few years before industry leaders fully realized that a grain of truth might lie behind the boasts of the oleoinargarine'salesinen.

The threat posed by inargarine became apparent, however, when the relative prosperity that had prevailed through 1877 gave way late in that year to a disastrous downturn in prices. Average wholesale Wisconsin butter in 1877 was only $16.3 \notin$ per pound and falling. ${ }^{117}$ By 1878, Wisconsin butter had dropped to $13.2 \notin$ per pound, recovering only slightly to $13.6 \$$ in 1879.118 As the following graph illustrates, national butter

Butter AND Margarine Prices, 1877-1886

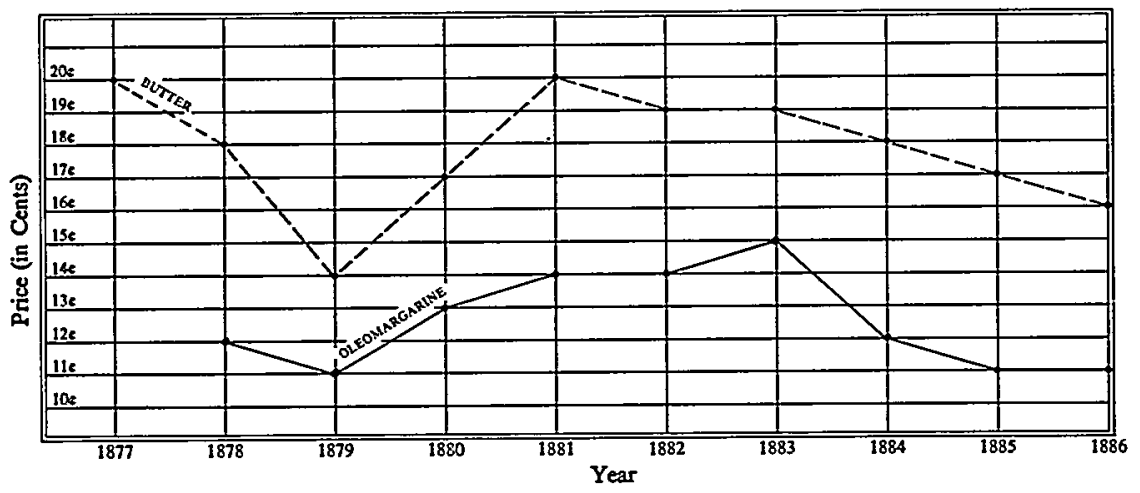

Source 1836 Hearings, supor note 15, at 164-85 (Anerican Agricultural and Dairy Association table).

prices reflected a similar downturn, falling froin approximately $20 \oplus$ per pound in 1877 to approxinnately $14 \nsubseteq$ per pound in $1879 .{ }^{119}$ The average value of milk cows fell rapidly during this period as well, dropping froin

116. M. TWAIN, LIFE ON THE MISSISSIPPI 328-29 (1923).

117. E. LAMPARD, supra note 2, at 455.

118. Id.

119. Source: 1886 Hearings, supra note 15 , at $184-85$. 
about $\$ 27.50$ in 1877 to approxinnately $\$ 21.50$ in $1879 .{ }^{120}$ The resulting hardship for dairy farmers and factory owners energized the forces of opposition to inargarine. ${ }^{121}$

\section{B. State Antimargarine Laws}

By 1877 , margarine's rapidly growing acceptance in cities across the country represented a serious threat to the dairy industry. When dairy industry leaders awoke to the threat, they quickly drew on the preexisting structure of industry organizations to press for legislative action.

\section{First-Generation Statutes}

State dairy associations, led by New York's association, first pressed for antimargarine protection in the form of labelling statutes sometime in 1877. New York's leadership in the first years of the campaign against inargarine resulted from a combination of factors. First, the leading American inargarme producer during the earliest years, the United States Dairy Company, was located in New York. ${ }^{122}$ Second, New York City, the state's primary butter inarket, was particularly vulnerable to competition froin margarme because of its large blue collar and immigrant population. Third, New York's large share of the butter market minimized the free-rider inhibitions against being the first to start a campaign against margarme. The dairymen of the first state to act against margarine would perform a free service for their fellow dairyinen in other states by drafting proposed legislation, adducing evidence necessary to support the proposal, developing a inodel of effective political organization that dairy interests im other states could emulate, and demonstrating that antimargarme legislation could actually be obtained. Because New York was the nation's leading dairy state, its dairymen would capture a greater percentage of the gains from their organizing efforts than would the dairymen from any other state. It was not surprising, therefore, that New York led the early battles against margarine.

New York enacted an antimargarine law in 1877 at the direct urging of the butter interests. ${ }^{123}$ Missouri followed suit the same year. ${ }^{124}$ Six states adopted labelling laws in 1878: California, ${ }^{125}$ Connecticut, ${ }^{126}$

120. See supra note 114 .

121. See W. PABST, supra note 2, at 30; see also M. OKUN, supra note 2, at 255-56.

122. See M. Okun, supra note 2 , at 252.

123. Act of June 5, 1877, ch. 415, 1877 N.Y. Laws 441. The title of the New York statute was "An act for the protection of dairymen, and to prevent deception in sales of butter." Id. See also M. OKUN, supra note 2, at 254-55.

124. Act of Apr. 28, 1877, 1877 Mo. Laws 319. Although the Missouri statute passed the legislature before the New York law, New York's law was approved and became effective a few weeks earlier than the one passed by Missouri. See id.; supra note 123.

125. Act of Mar. 26, 1878, ch. 352, 1877-78 Cal. Stat. 535. 
Maryland, ${ }^{127}$ Massachusetts, ${ }^{128}$ Ohio, ${ }^{129}$ and Pennsylvania. ${ }^{130}$ Three more states passed legislation in 1879: Delaware, ${ }^{131}$ Illinois, ${ }^{132}$ and Tennessee. ${ }^{133}$ Others soon fell into line; by 1886 , thirty-four states and territories had enacted some version of margarine labelling legislation. ${ }^{134}$

These first-generation antinnargarine statutes ostensibly countered the problem of palming-off by requiring proper labelling, prescribing penalties for fraudulent misrepresentation, or both. ${ }^{135}$ The original Wisconsin law, for exainple, required that imitation butter made with tallow (beef fat) be labelled "oleomargarine" in half-inch letters, and, if inade with lard, be labelled "butterine."136 Soine statutes required hotels, restaurants, and boarding houses to post public notices if they served margarine to guests. ${ }^{137}$

These statutes were desigued to eliminate a particular lemons problein in retail butter inarkets. If consumers could not easily distinguish margarine from butter, then sellers would have an incentive to substitute margarine for the more expensive product. The first-generation statutes, if effectively enforced, could alleviate this narket breakdown. Accordingly, the dairy interests had little trouble portraying the ineasures they sought as protecting the public interest.

Although the first-generation statutes appeared justifiable as public interest measures, ${ }^{138}$ the dairy industry's support for tliese laws was no

126. Act of Mar. 27, 1878, ch. 121, 1878 Conn. Pub. Acts 337.

127. Act of Apr. 5, 1878, ch. 493, 1878 Md. Laws 826.

128. Act of Apr. 3, 1878, ch. 106, 1878 Mass. Acts 70.

129. Act of May 15, 1878, 1878 Ohio Laws 558.

130. Act of May 22, 1878, No. 112, $1878 \mathrm{~Pa}$. Laws 87 . The Pennsylvania law was submitted for advance approval to organizations such as the Solebury Farmers' Club, the Bucks County Agricultural Society, and the Doylestown Agricultural and Mechanics Institute. E. W1EST, supra note 2 , at 237 .

131. Act of Feb. 10, 1879, ch. 154, 16 Del. Laws 223.

132. Act of May 31, 1879, 1879 IIl. Laws 95.

133. Act of Mar. 24, 1879, ch. 169, 1879 Tem1. Acts 212.

134. See Act of Apr. 2, 1885, No. 127, 1885 Ark. Acts 204; Act of Apr. 6, 1885, 1885 Colo. Sess. Laws 282; Act of Mar. 10, 1885, ch. 64, §§ 3-7, 1885 Dakota Laws 110; Act of Feb. 17, 1881, ch. 3280, No. 62, 1881 Fla. Laws 84; Act of Sept. 21, 1883, No. 261, 1882-83 Ga. Laws 124; Act of Jan. 27, 1885, 1884-85 Idaho Sess. Laws 61; Act of Mar. 3, 1883, ch. 62, 1883 Ind. Acts 78; Act of Mar. 12, 1880, ch. 39, 1880 Iowa Acts 34; Act of Feb. 28, 1883, ch. 154, 1883 Me. Acts 125; Act of June 10, 1881, No. 254, 1881 Mich. Pub. Acts 346; Act of Mar. 2, 1881, ch. 133, 1881 Minn. Laws 175; Act of Mar. 9, 1882, ch. 50, 1882 Miss. Laws 85; Act of Mar. 10, 1885, 1885 Mont. Laws 51; Act of Feb. 20, 1883, ch. 53, 1883 Neb. Laws 239; Act of Feb. 4, 1881, ch. 14, 1881 Nev. Stat. 24; Act of Aug. 11, 1881, ch. 57, 1881 N.H. Laws 476; Act of Feb. 21, 1884, ch. 15, 1884 N.J. Laws 24; Act of Feb. 25, 1885, 1885 Or. Laws 127; Act of June 8, 1880, ch. 829, 1880 R.I. Acts \& Resolves 8; Act of Feb. 10, 1880, ch. 64, 1879-80 Va. Acts 49; Act of Nov. 25, 1884, No. 88, 1884 Vt. Laws 82; Act of Feb. 4, 1886, 1885-86 Wash. Laws 118; Act of Mar. 3, 1881, ch. 40, 1881 Wis. Laws 39.

135. See K. SNODGRASs, supra note 2, at 89-90.

136. Act of Mar. 3, 1881, ch. 40, 1881 Wis. Laws 39.

137. See, e.g., Act of Sept. 21, 1883, No. 261, 1882-83 Ga. Laws 124.

138. The economic justification for these statutes can be rephrased in modern terminology using Akerlof's "lemons" model, discussed at supra notes 55-71 and accoinpanying text. According to 
doubt also motivated by a less benign purpose. As late as 1886 , members of the industry professed the view that most consuiners would not knowingly eat oleomargarine if given the choice. ${ }^{139}$ Presuinably those sentiments were even stronger in the earliest days of the conflict between 1nargarine and butter. Dairy industry leaders probably believed that the first-generation laws would not only inform consuners, but would also effectively drive inargarine out of business.

Unfortunately for the dairy industry, the first-generation statutes failed to accoinphish either their explicit purpose of eliminating market fraud or their implicit purpose of destroying the margarine industry. First, neither the executive nor the judicial branches of the government vigorously enforced the antimargarine laws. Judges often sympathized with the phight of retailers charged with purveying a harmless food item. ${ }^{140}$ Prosecutors were reluctant to pursue margarine cases which were time-consuining and expensive, requiring the services of undercover agents and analytic chemists as well as lawyers. ${ }^{141}$ Accordingly, law enforcement officials typically devoted little time or effort to enforcing the inargarine laws. ${ }^{142}$

The low penalties for violations posed an additional enforcement problein. Even when prosecutions did occur, margarine distributors could afford to simply pay their fines and continue in business. ${ }^{143}$ Presumably even a low probability of prosecution could have achieved significant deterrence, if high penalties for violations of these statutes were

Akerlof's scenario, some merchants who knew that consumers could not easily tell the difference between butter and margarine would palm off margarine as butter. Consumers, however, would come to realize that they were likely to receive margarine rather than butter and, accordingly, would lower the amount they were willing to pay for any table spread or shortening agent. As the market price went down, butter would be driven off the market, to be replaced by margarine. Eventually consumers who desired to purchase butter would be unable to do so. This scenario of market breakdown provides a solid contemporary economic justification of the first-generation statutes (assuming the accuracy of the factual premises that consumers could not easily distinguish butter and margarine and that some of them would be willing to pay premium prices for genuine butter).

139. See, e.g., 17 CONG. REc. 4894 (1886) (remarks of Rep. Millard); id. at 4901 (remarks of Rep. Frederick).

140. See, e.g., 1886 Hearings, supra note 15, at 7 (remarks of L.I. Seaman) ("[T] here appear to be so many milk-and-water judges on the bench, who seem to regard the violation of the [margarine] law in the hight that they do some other unimportant violations of it, that it is an exception when a man is fined even.").

141. One of the earliest margarine prosecutions in New York fell apart when the experts failed to agree on whether the chief exhibit was margarine or butter. M. OkUN, supra note 2, at 256. See also 1886 Hearings, supra note 15, at 9 (remarks of Gardiner B. Chapin).

142. See 1886 Hearings, supra note 15, at 9 (remarks of Gardiner B. Chapin) (state antimargarine laws are "not generally executed at all"); $i d$. at 11 (remarks of James Hughes); $i d$. at 13 (remarks of Victor E. Piollet)

143. See 1886 Hearings, supra note 15 , at 7 (remarks of L.I. Seaman) ("These people violate the law, and then when they are arrested and convicted they pay the fine of $\$ 100$ and go back and repeat the offense, and yet make money by it"); id. at 11 (remarks of James Hughes). 
imposed. ${ }^{144}$ However, increased penalties would probably have been counterproductive; judges, juries and prosecutors would have even greater incentives to nullify the antimargarine laws. Accordingly, under a system of separation of powers in which the laws were enforced by prosecutors and judges of general jurisdiction, the dairy industry could not achieve an acceptable level of enforceinent. Palming-off apparently continued to be a serious problem. ${ }^{145}$

A second major problem was consumers' continuing deinand for margarine over butter, due in part to a significant price differential. Although statistics on margarine production are not available for this period, the evidence indicates that the inargarine trade was booming. Margarine prices increased froin $11 \notin$ per pound in 1879 to $13 \notin$ per pound in $1880,{ }^{146}$ suggesting an increase in deinand. The jump in butter prices between 1879 (14థ per pound) and 1880 (17థ per pound) also suggests increased margarine demand ${ }^{147}$ since margarine is a substitute for butter and increases in butter prices undoubtedly increased the demand for inargarine. The rapid increase in inargarine sales between 1880-1886 indicates that margarine quickly gained consuiner acceptance.

\section{Prohibitory Statutes}

Despite the mcreased margarine trade, dairy forces failed to undertake any significant new mitiatives during the period from 1879 to 1883. ${ }^{148}$ This inay be explained by the profitability of dairying during this period. Butter prices rose to 204 per pound in 1881 and remained close to that level through $1883 .{ }^{149}$ Butter exports surged froin 21.5 mil-

144. See generally Becker, Crime and Punishment: An Economic Analysis, 76 J. Pol. EcoN. 169 (1968) (discussing the relationship between frequency of enforcement and size of sanction in deterring crime); Stigler, The Optimum Enforcement of the Laws, 78 J. Pol. EcoN. 526 (1970) (discussing the conditions for optimum enforcement in terms of costs of enforcement and costs of violations).

145. See 1886 Hearings, supra note 15, at 8-9 (remarks of Gardmer B. Chapin).

146. See id. at 184-85.

147. See id.

148. The industry did, however, continue to press for labelling legislation in additional states, see supra note 134, and did inake desultory efforts to obtain federal protection, see infra notes 204205.

149. See 1886 Hearings, supra note 15, at 27 (reinarks of S.P. Hibbard) (dairying a prosperous business in 1880 and part of 1881). At least one industry representative testified in 1886 that business had been depressed for a number of years prior to 1883 , but the statement refers to special conditions in the New York fluid milk market where dealers had apparently formed a buyers' cartel to drive prices down. See 1886 Hearings, supra note 15, at 25 (statement of W.P. Richardson). 
hon pounds in 1878 to 39.5 million pounds in $1880 .{ }^{150}$ Just as the depressed condition in the industry precipitated the initial cainpaign of 1877 , the ensuing prosperity of $1880-1883$ dampened any desire to continue an aggressive campaign.

Sometime in 1883 , however, butter prices began to break, falling to $18 \Phi$ per pound in $1884,17 \Phi$ per pound in 1885 , and $16 \Phi$ per pound in 1886. ${ }^{151}$ The situation in export markets was also troubhing. Margarine exports, which had risen rather steadily since 1877 , exceeded butter exports for the first time in 1882. By 1883, margarine exports had risen sharply (from 21 to 31 million pounds) while butter exports had plummeted (from 14.5 to 12.5 milhion pounds). ${ }^{152}$

Although butter exports recovered somewhat after 1883, rising to over 20 million pounds in $1885,{ }^{153}$ they remained far below inargarine exports. The one unambiguousiy positive sign for dairy farmers was the price of milk cows, which rose sharply between 1879 ( $\$ 21.50$ per cow) and 1884 ( $\$ 31.50$ per cow). ${ }^{154}$ The value of milk cows dropped during the following two years, however, falling to $\$ 29.50$ in 1885 and $\$ 27.50$ in $1886 .{ }^{155}$ Accordingly, dairy farmers' complaints about the industry's depressed conditions increased between 1883 and $1886 .{ }^{156}$

The economic downturn sparked a new round of antinargarine

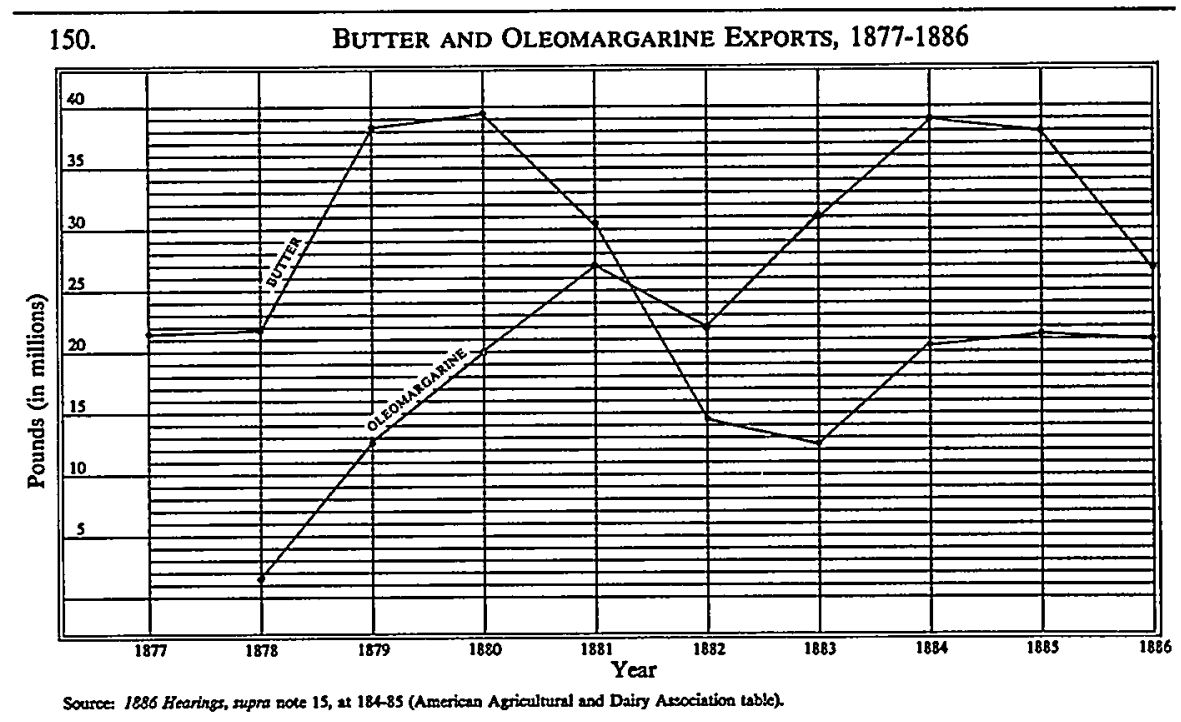

151. See id. and accompanying text.

152. See id.

153. See id.

154. See supra note 114 .

155. See id.

156. See 1886 Hearings, supra note 15, at 25-26 (statement of W.P. Richardson) ("depression in the butter counties"); id. at 28 (statement of S.P. Hibbard); id. at 31-33 (statement of G.W. Martin). 
activity by the dairy lobby, even though the decline in butter prices evidently suppressed the margarine trade during those years as well. ${ }^{157}$ To counter the continued threat of margarine, dairy interests in several states obtained progressively inore stringent antimargarine laws. These laws represented a major shift in regulatory philosophy, inoving away from labelling legislation toward prohibitory legislation that outlawed margarine altogether. ${ }^{158}$

The moveinent for prohibitory legislation quickly gained moinentum. By 1886 nine states had enacted prohibitory statutes: Maine, ${ }^{159}$ Michigan, ${ }^{160}$ Minnesota, ${ }^{161}$ Missouri, ${ }^{162}$ New Jersey, ${ }^{163}$ New York, ${ }^{164}$ Ohio, ${ }^{165}$ Pennsylvania, ${ }^{166}$ and Wisconsin. ${ }^{167}$ New Hainpshire whimsically required that margarine be colored pink. ${ }^{168}$ Not surprisingly, most of the states enacting prohibitory legislation were annong the nation's leading dairy states in $1886 .{ }^{169}$

Prohibitory legislation held a number of advantages over the earher labelling laws. It was easier to enforce because it could be applied against a small group of manufacturers and wholesalers rather than a large, dispersed, and shifting retail class. More importantly, if effectively enforced, it not only eliminated the problem of fraud but also threatened to ehminate competition from inargarine altogether. Many of these sec-

157. Margarine fell from $15 £$ per pound in 1883 to $11 \uparrow$ per pound in 1886 , probably reflecting reduced demand caused by lower butter prices. See supra note 119 and accompanying text.

158. Pennsylvania's prohibitory statute, enacted in 1885 , was typical. It provided in pertinent part that "no person ... shall manufacture out of any oleaginous substance . . . any article designed to take the place of butter ... produced from pure unadulterated milk, or cream from the same ... nor shall sell or offer for sale, or have in his ... possession with intent to sell the same as an article of food." Act of May 21, 1885, No. 25, 1885 Pa. Laws 22.

159. Act of Mar. 3, 1885, ch. 297, 1885 Me. Acts 247.

160. Act of June 12, 1885, no. 186, 1885 Mich. Pub. Acts 256.

161. Act of Mar. 5, 1885, ch. 149, 1885 Minn. Laws 189.

162. Act of Mar. 24, 1881, 1881 Mo. Laws 120.

163. Act of May 5, 1884, ch. CXCIV, 1884 N.J. Laws 289.

164. Act of Apr. 24, 1884, ch. 202, 1884 N.Y. Laws 255.

165. Act of Apr. 27, 1885, no. 705, 1885 Ohio Laws 159.

166. Act of May 21, 1885, supra note 158 .

167. Act of Apr. 8, 1885, ch. 361, 1885 Wis. Laws 333.

168. Act of Aug. 26, 1885, ch. 68, 1885 N.H. Laws 269.

169.

\begin{tabular}{lrr}
\multicolumn{1}{c}{ States } & Population & $\begin{array}{c}\text { Butter Produced } \\
\text { (Pounds) }\end{array}$ \\
\hline Illinois & $3,077,871$ & $53,657,943$ \\
Indiana & $1,978,301$ & $37,377,797$ \\
Iowa & $1,624,615$ & $55,481,958$ \\
Kansas & 996,096 & $21,671,762$ \\
Michigan & $1,636,937$ & $38,821,890$ \\
Minnesota & 780,773 & $19,161,385$ \\
Missouri & $2,168,380$ & $28,572,124$ \\
New York & $5,082,871$ & $111,922,423$ \\
Ohio & $3,198,062$ & $67,634,263$
\end{tabular}


ond-generation state statutes included viable enforcement mechanisms to remedy the notorious inefficacy of the labelling legislation. Again New York took the lead, estabhishing in 1884 an office of dairy commissioner specifically charged with uncovering and prosecuting violations of the margarine law. ${ }^{170}$ The State provided the commissioner with a generous budget, a force of inspectors, and staff experts to document whether substances sold as butter were actually margarine. ${ }^{171}$

The legislative creation of imdependent departments specifically charged with enforcing the margarine laws provided a means of circumventing some of the obstacles to effective interest group activity created by the separation of powers. To be sure, the dairy commissions did not exercise judicial or legislative functions: their role was to detect and prosecute offenses of existing law before courts of general jurisdiction. Their functions were purely executive in nature. However, their specific legislative mandate-focused as it was on one particular industry-substantially undercut the prosecutorial discretion that had stymied earlier efforts to enforce the margarine laws. Created to enforce the antimargarine laws with vigor, the commissioners responded to the expectations of the dairy interests. In this respect the dairy coinmission was a precursor of the independent regulatory agency, a device that grew in later years to circumvent the barriers to interest group activity under a system of separation of powers. ${ }^{172}$

From the dairy interests' viewpoint, prohibitory legislation's principal advantage lay in its elimination of all competition from margarine. At the same time, however, this effect also weakened the legal case for such legislation. Prohibitory legislation was obviously overinclusive if its goal was to attack fraud. In stamping out fraud, it would also prevent legitimate competition from margarine. The dairy industry therefore began to supplement the fraud contention with the arguinent that margarine was dangerous to the public health. Legislation baming the product outright could be justified easily if margarine were shown to be unhealthful.

In support of its public health claim, the dairy interests charged that margarine caused dyspepsia and a host of other ailments. ${ }^{173}$ The industry fomented claims that margarine contained diseased or putrid beef,

170. Act of Apr. 29, 1884, ch. 202, §9, 1884 N.Y. Laws 255, 257.

171. Id. The state appropriated $\$ 30,000$ a year for the dairy commission. Id. In two years the dairy commission made over 300 arrests and obtained nearly 100 convictions. 1886 Hearings, supra note 15, at 20 (statement of B.F. Van Valkenburgh, assistant dairy commissioner). Despite these efforts, however, enforcement problems persisted in New York. Id. at 20-21.

172. See generally Miller, Independent Agencies, 1986 SUP. CT. REv. 41, 74 ("agency independence provides a useful mechanism for compromise and accommodation among competing political interest groups.")

173. See, e.g., H.R. REP. No. 2028, 49th Cong., 1st Sess. 2 (1886). 
dead horses, dead hogs, dead dogs, mad dogs, and drowned sheep. ${ }^{174}$ In New York, dairy interests engineered an investigation into inargarine by the state senate's public health committee. ${ }^{175}$ Managed by friends of the dairy imdustry, the investigation proved hittle more than a witchhunt. The committee received "evidence" that inargarine was inade with the worst sorts of filthy grease, that workmen had lost toenails because of the process, and so on. ${ }^{176}$ Just as the committee heard all kinds of farfetched charges, the case in favor of margarine's healthfulness was suppressed. Emment authorities, such as Professor Charles I. Chandler of Columbia College, a former president of the New York City Board of Health, were interviewed but not called before the committee when it became evident that they would testify to the healthfulness of inargarine. ${ }^{177}$ Not surprisingly, the committee recommended total prolnibition of margarine. ${ }^{178}$

The charge that inargarine was unhealthful, however, was exceedingly weak. Margarine and butter were virtually identical in chemical composition. ${ }^{179}$ Even the dairy commissioner of New York failed to uncover any evidence that the coinponents of inargarine were harmful, despite having expended several years and inuch inoney in efforts to do so. ${ }^{180}$ The fact that margarine was notling more than a mixture of ingredients universally recognized as healthful demonstrated the futility of the task. Nor was there inerit to the charge that the fat of decaying or diseased amimals was used in inargarine. Recognized nutritional scientists testified that ouly the freshest and lnghest quahty fats could be used in inanufacturing inargarine. ${ }^{181}$

Moreover, the dairy industry's charges were somewhat hypocritical given the unsanitary conditions prevailing in that industry at the time. Raw milk was produced on thousands of farms across the country where sanitation was unknown. ${ }^{182}$ Flies, straw, and dung contaminated inany milking stalls. Milk arrived at creaineries in cans containing an inven-

174. See, e.g., 1886 Hearings, supra note 15 , at $35,41,46$.

175. See M. OKUN, supra note 2, at 274-75.

176. 1886 Hearings, supra note 15, at 68 (remarks of Charles I. Chandler).

177. See id. Chandler's credibility, however, is not entirely above suspicion, since he had previously served as an expert witness for the United States Dairy Company in actions for infringement of the Mège patent. M. OKuN, supra note 2, at 272.

178. M. OKUN, supra note 2 , at 275.

179. E.g., 1886 Hearings, supra note 15, at 72-73.

180. Id. at 22 (statement of B.F. Van Valkenburgh). Although the commissioner conceded that chemistry could not prove that margarine was unhealthy, he did argue that the substance could cause physiologieal harm. Id.

181. E.g., id. at 60 (statement of Prof. Henry Morton).

182. A leading dairy authority stated as late as 1916 that "[t]he unsanitary conditions under which the greater portion of the supply of milk is produced and marketed is a rebuke to society .... [O]n a great many farms, where dairying is not specialized, sanitation is very sadly neglected." $E$. WIEST, supra note 2 , at 15. 
tory of daily farm life-bars of soap, dishrags, potatoes, parsnips, and hairpins, together with the product of the cow that lent such fertility to its pastures. ${ }^{183}$ Health experts nurtured a strong-and ultinately justified-suspicion that dairy products often transmitted tuberculosis, a inajor cause of human inortality.$^{184}$ Not surprisingly, microscopists who testified about the existence of bacteria in margarme were not invited to investigate butter similarly. ${ }^{185}$

Even so, the industry successfully maintained its bogus charges against inargarime for a time. A House of Representatives committee concluded that inargarme was "detrimental to the public health, being the fruitful cause of dyspepsia and other diseases."186 The United States Supreme Court accepted findings that inargarine inight be dangerous to health in upholding Pennsylvarria's prohibitory statute. ${ }^{187}$

Prohibitory legislation held the promise of effectively denying consumers access to inargarine even if they affirmatively desired to buy the product. Nevertheless, prohibitory legislation at the state level was not wholly satisfactory to the dairy interests. For one thing, prohibitory legislation was much more difficult to obtain than labelling laws. States with weak dairy lobbies were unlikely to enact such legislation. As noted above, ${ }^{188}$ by 1886 such legislation had passed only in those relatively few states with strong dairy interests. Thus, a strategy directed solely at enactinent of prohibitory legislation at the state level would not effectively prohibit inargarme nationwide.

Second, prohibitory legislation, while relatively easy to enforce against $\mathrm{m}$-state manufacturers of inargarine, could not bar the production of inargarme in other states. Out-of-state manufacturers easily could ship margarine to wholesalers in states with prohibitory statutes, which could then be distributed to retailers for sale to the public. ${ }^{189}$ Euforcing prohibitory legislation against these in-state retailers and wholesalers proved exceedingly difficult. Not only was detecting margarine sales by retailers expensive, but even if the retailer were prosecuted,

183. See 1900 House Hearings, supra note 62, at 121 (statement of John Dadie, Esq.).

184. See, e.g., 1886 Hearings, supra note 15, at 64 (statement of Professor Henry Morton); 1900 House Hearings, supra note 62, at 121 (statement of John Dadie, Esq.); E. GuTHR1E, supra note 19, at $96-98$.

185. See 1886 Hearings, supra note 15, at 45 (statement of Dr. Thomas Taylor) (explaining that no analysis was made of butter because "it is generally supposed that butter is made from healthy cows"). Any microscopic investigation of butter would have discovered bacteria galore. See E. GUTHRIE, supra note 19, at 35-44, 177-80.

186. H.R. REP. No. 2028, supra note 173 , at 2.

187. Powell v. Pennsylvania, 127 U.S. 678, 684-86 (1888)(declaring Pennsylvania's prohibitory statute to be a legitimate exercise of police power to protect public health).

188. See supra notes 159-170 and accompanying text.

189. See 1886 Hearings, supra note 15, at 20 (statement of B.F. Van Valkenburgh); id. at 152 (statement of James H. Seymour); 17 CoNG. REc. 4911 (1886) (remarks of Rep. Henderson). 
the chances of conviction were low because of sympathetic judges and juries. ${ }^{190}$

The failure of state prohibitory legislation to cut off interstate commerce in margarine illustrates how the system of federalism, otherwise beneficial to the dairy industry, inhibited its campaign in one respect. In a unitary system, the dairy industry might have eliminated margarine through system-wide prohibitory legislation that could have been enforced against manufacturers throughout the country. In a federal systen, however, the industry could not prohibit margarine completely. Prohibitory legislation in individual states would not eradicate in-state margarine sales if the substance could be mannfactured elsewhere-especially if (as the Supreme Court later ruled) ${ }^{191}$ the commerce clause $\mathrm{hm}$ ited state power to restrain interstate shipinents. Furthermore, even federal prohibitory legislation would not eliminate all manufacture if (as the Court also later ruled) ${ }^{192}$ the federal government had no right to regulate manufacturers witlim a state. ${ }^{193}$

The danger of judicial invalidation proved to be another drawback of prohibitory legislation. Effective enforcenent of the prohibitory laws required judicial, as well as executive, action. Although the problem of executive enforcenent could be remedied to sonie extent by legislation estabhishing specialized agencies with strong enforcement incentives, it proved much more difficult for the dairy industry to elicit cooperation fron the judiciary. Constitutional prohibitions could not be overturned by legislation. It was difficult, even in states with elected judiciaries, to bring direct political pressure to bear on state judges. Thus, the dairy industry's voting power was relatively ineffective in stimulating favorable judicial action.

In People v. Marx, ${ }^{194}$ the margarine forces finally achieved the constitutional victory they had sought. ${ }^{195}$ The New York Court of Appeals declared a prohibitory statute unconstitutional as interfering with hiberty

190. See 1886 Hearings, supra note 15, at 20-21 (statement of B.F. Van Valkenburgh); id. at 169 (statement of W.S. Truesdell).

191. Leisy v. Hardin, 135 U.S. 100, 124-25 (1890) (invalidating state statute prohibiting sale of out-of-state liquors).

192. United States v. E.C. Knight Co., 156 U.S. 1, 12-13 (1895) (control of manufacturing not subject to regulation under commerce clause).

193. Both these impediments have since been overcome, thus significantly reducing the degree to which federalism inhibits interest group activity. See Wickard v. Filburn, 317 U.S. 111 (1942) (effectively overruhing E.C. Knight); Plumley v. Massachusets, 155 U.S. 461, $478-79$ (1894) (sustaining state statute prohibiting sale of margarine colored to look like butter).

194. 99 N.Y. 377, 2 N.E. 29 (1885).

195. A prohibitory statute in Missouri had earlier been upheld, the court observing that "the legislature may do many things in the legitimate exercise of [the police] and other powers, which, however unwise or mjudicious they may be, are not obnoxious to the objeetion of being beyond the scope of legislative authority." State v. Addington, 77 Mo. 110, 117 (1882). 
of contract. ${ }^{196}$ On the basis of expert trial testimony, the court found that margarine was both healthful and virtually indistinguishable chemically from butter. ${ }^{197}$ Moreover, the court took judicial notice that the law's purpose was to suppress the manufacture and sale of margarine, that the law had been passed at the behest of the dairy industry, that it effectively expropriated the capital of margarine producers, and that as a consequence of the prohibition, "such of the people of the State as cannot afford to buy dairy butter must eat their bread unbuttered." 198

The Marx opinion recognized that the challenged legislation represented something new in the politics of the state-a phenomenon that if allowed to develop into a trend would carry pernicious consequences for the public at large. The sole reason for the New York statute, said the court, was to keep butter prices high by suppressing competition from margarine. ${ }^{199}$ According to the court, "[m]easures of this kind are dangerous even to their promoters," 200 because if the principle of protectionism were constitutionally sustained, its reach could not be limited to any particular industry. On the contrary, margarine inanufacturers could suppress the dairy industry if they obtained enough legislative clout. ${ }^{201}$ The court warned that "[i]llustrations inight be indefinitely multiplied of the evils which would result from legislation which should exclude one class of citizens from industries, lawful in other respects, in order to protect another class against competition. We cannot doubt that such legislation is [unconstitutional]." 202

The Marx case significantly set back dairy interests. A decision by the highest court of the nation's largest dairy state, especially one written in such a tone of moral outrage, was damaging enough. More iminediately, Marx opened up the massive New York City market to the margarine business-a potentially devastating blow to the powerful dairy interests in Orange County and elsewhere in the state. The dairy industry responded, as seen in Part III, with a renewed effort to check margarine production on the federal level.

\section{III}

The Federal Statute of 1886

\section{A. The Proposed Statute}

Federal legislation had been on the agenda of various dairy leaders

196. Marx, 99 N.Y. at $386-87,2$ N.E. at $33-34$.

197. Id. at $381-82,2$ N.E. at 30.

198. See id. at 383-87, 2 N.E. at 31-34.

199. Id. at 387,2 N.E. at 33.

200. Id.

201. Id.

202. Id. at 387,2 N.E. at 34 . 
since about 1880. The National Association for the Prevention of the Adulteration of Butter (NAPAB), a group of dairymen and butter merchants formed in 1879 and headquartered in New York, ${ }^{203}$ spearheaded the imitial efforts. Although it focused most of its efforts in New York, this group also lobbied dairy state representatives in Congress. In $1880^{204}$ an Illinois congressman introduced a bill to tax margarine at $10 \$$ per pound. A House committee held hearings on the subject in 1882 and recoinmended passage of antimargarine legislation. ${ }^{205}$ These imitiatives were rather desultory; no powerful national campaign against margarine existed prior to 1885 .

In 1885 , however, several forces combined to stimulate a successful campaign for federal antinargarine legislation. First and most important, dairy industry conditions suffered a downturn. In 1883, butter sold for $19 \$$ per pound but dropped the following year to $18 \$$ per pound, and in 1885 to $17 \uparrow$ per pound. ${ }^{206}$ The situation became especially serious in Wisconsin, where prices dropped from $19.2 \$$ per pound in 1882 to $14.1 \$$ per pound in 1885. ${ }^{207}$ At the saine time, the value of milk cows dropped by almost a quarter. ${ }^{208}$ Large numbers of cows were slaughtered in the Chicago stockyards because they were worth more as carcasses than as milk producers. ${ }^{209}$

Second, by 1885 margarine had become a major industry. Estimates of nationwide margarine production in 1886 ranged froin two hundred million pounds per year (the dairy industry's figure) ${ }^{210}$ to between thirtytwo and thirty-five million pounds (a margarine manufacturer's estimate). ${ }^{211}$ Whatever the actual figures, margarine production was clearly big business in 1886 .

Margarine also gained a strong competitive position in the export market during this time. In 1880, approxinately forty million pounds of butter were exported as compared with twenty million pounds of margarine. By 1885 their positions were almost perfectly reversed; butter exports had fallen to only approximately twenty-two million pounds while margarine exports had increased to over thirty-seven million

203. M. OKUN, supra note 2, at 256.

204. Id. at 261-63.

205. See Manufacture and Sale of Oleomargarine, H.R. REP. No. 1529, 47th Cong., 1st Sess. (1882).

206. See supra notes $149 \& 151$ and accompanying text.

207. E. LAMPARD, supra note 2, at 455.

208. H.R. REP. No. 2028, supra note 173, at 2 (reporting that the value of milk cows had dropped from $\$ 40$ per head to $\$ 30$ per head, representing a total capital loss of $\$ 150,000,000$ ).

209. See id. (300,000 milk cows slaughtered in 1885 in Chicago alone).

210. Id. This figure may have represented as inuch as one-fifth of the nation's annual production of butter. See 17 CoNG. REc. 4865 (1886) (remarks of Rep. Scott).

211. 1886 Hearings, supra note 15, at 224 (statement of George $\mathbf{H}$. Webster). 
pounds. $^{212}$

Decided in June of 1885 , the Marx case provided the third and perhaps most immediate stimulus to the dairy industry's federal campaign, convincing industry leaders that they could not rely upon state governments to protect their interests adequately. ${ }^{213}$ They required a national strategy as well. Although, as will be noted, ${ }^{214}$ federal prohibitory legislation also faced constitutional difficulties, the industry had reason to hope that the federal taxing power could accomplish what the state police power had failed to do in New York. ${ }^{215}$

To organize a federal campaign, the American Agricultural and Dairy Association-successor to the New York organization formed twenty years earher ${ }^{216}$ —called a national convention of dairymen in New York City early in $1885 .^{217}$ Delegates came froin twenty-six states and all sectors of the industry. Their nuinbers included representatives of state governors, delegates froin state agricultural societies and boards of agriculture, state and local dairy associations and granges, and representatives of the produce and inercantile exchanges of New York and other cities. $^{218}$

Under the leadership of a New York dairyman, the convention agreed to a bold plan of seeking federal legislation designed to suppress the margarine industry. ${ }^{219}$ As it emerged from the House Committee on Agriculture, their legislation combined both prohibitory and regulatory aspects. The prohibitory part of the bill involved a tax of ten cents per pound. ${ }^{220}$ The tax would raise the price of margarine at least as high as that of creamery butter, destroying margarine's commercial viability. The proposal's regulatory aspect required that margarine be labelled as such.221 Margarine found to contain imgredients deleterious to human health would be confiscated and forfeited. ${ }^{222}$ The bill required manufacturers, wholesalers, and retailers of margarine to obtain licenses to carry on their trade, for which they had to pay large fees: $\$ 600$ for manufacturers, $\$ 480$ for wholesalers, and $\$ 48$ for retailers. ${ }^{223}$ The bill also imposed

212. See supra notes $150 \& 153$ and accompanying text.

213. See 17 CoNG. Rec. 4894 (1886) (remarks of Rep. Millard) (observing that the New York legislature had attempted in vain to regulate the margarine business in that state).

214. See infra notes $226-229$ and accompanying text.

215. See id.

216. See supra note 74 and accompanying text.

217. See 1886 Hearings, supra note 15, at 238 (statement of F.K. Moreland, counsel to the American Agricultural and Dairy Association).

218. See 17 CoNG. REC. 4865 (1886) (remarks of Rep. Scott).

219. See M. OKUN, supra note 2, at 100, 279.

220. 17 CONG. REC. 5055 (1886).

221. Id. at 5053,5173 .

222. Id. at 5166 .

223. See id. at 4977. 
fines and criminal penalties for violations, and charged the Commissioner of Internal Revenue with responsibihty for collecting the tax and for prescribing regulations fleshing out the statutory requirements. ${ }^{224}$

A sophisticated piece of legislative drafting, the bill drew on prior state legislation, borrowing those features that had been successful and scrapping the parts that had proved ineffective. Consequently, it was cleverly framed to emphasize the dairy industry's asserted public interest rationales for limiting margarine. The labelling requirements were ostensibly designed to deter fraudulent sales of margarine as butter, while the inspection and forfeiture provisions were supposedly intended to deal witl the alleged unhealthful conditions of margarine inanufacture. The taxing and licensing features could be presented as revenue ineasures designed to support the costs of enforcing the regulatory provisions. The taxing provisions of the bill also provided a rationale for vesting enforcement responsibility in the Commissioner of Internal Revenue, an official who enjoyed a considerable reputation for vigorous enforcement of the revenue laws. ${ }^{225}$

At the same time, the bill seemed reasonably calculated to survive constitutional challenge. The federal government's power to prohibit margarine outriglit was questionable. For one thing, express prohibition would be subject to the same type of substantive due process objections that had doomed tlie New York statute in that state's highest court. ${ }^{226}$ Perhaps more important, an absolute prohibition on all margarine sales and manufacture would almost certainly have run afoul of the commerce clause as then interpreted. ${ }^{227}$

On the other hand, the Supreme Court's decisions suggested that the taxing power provided a broader source of federal authority than the commerce power. ${ }^{228}$ The federal governinent's taxing authority was not linited to matters in interstate commerce. Thus Congress could tax the manufacture and intrastate sale of margarine even if it could not regulate these inatters directly under the commerce clause. Moreover, the Supreme Court liad already upheld a statute inposing a prohibitory federal tax on state bank notes, ${ }^{229}$ suggesting that even a prohibitory margarine tax miglit be upheld.

224. See id. at 5037, 5044, 5161. The text of the bill (with one important amendment discussed below) was substantially similar to the provision eventually enacted into law. See Act of Aug. 2, 1886, ch. 840, 24 Stat. 209, 212-13.

225. See 1886 Hearings, supra note 15, at 11 (statement of James Hughes).

226. See supra text accompanying notes 194-202.

227. The Supreme Court ruled that manufacturing was beyond the reach of federal power under the commerce clause in United States v. E.C. Knight Co., 156 U.S. 1 (1895).

228. See D. Currie, The Constitution in the Supreme Court 317-20 (1985).

229. Veazie Bank v. Fenno, 75 U.S. (8 Wall.) 533 (1869). 


\section{B. Congressional Consideration}

The dairy industry had no difficulty finding willing sponsors for its proposal in the House of Representatives. ${ }^{230}$ The political pressures brought to bear by the dairy industry were remarkable for the time and respectable even by the standards of today's Congress. The dairy interests in the various states organized a massive letter-writing campaign, generating over 104,000 petitions for the bill. The inost intense pressure, as might be expected, caine from the big dairy states: New York $(21,923$ petitions), Pemisylvania $(15,487)$, Iowa $(11,601)$, Ohio $(10,081)$, Minnesota $(8,282)$, Illinois $(7,533)$, and Wisconsin $(6,482) .{ }^{231}$ The bill was heavily lobbied by state and local granges, national producer groups such as the National Butter, Cheese and Egg Association, the American Agricultural Association, the American Agricultural and Dairy Association, ${ }^{232}$ state and local producer or creamery groups, ${ }^{233}$ dairy merchants and produce exchanges, ${ }^{234}$ the New York Dairy Coinınission, ${ }^{235}$ a leader of a producers' cartel, ${ }^{236}$ and individual factory dairymen. ${ }^{237}$ In this manner, many of the dairy organizations described earlier in this Arti$\mathrm{cle}^{238}$ contributed to the political pressure in favor of the proposed federal statute.

The bill's opponents included margarine producers, western cattlemen anxious to protect a market for beef fat, various boards of trade, labor organizations, and cotton producers who wanted to protect an incipient market for cottonseed oil. ${ }^{239}$ But unlike the well-organized but-

230. Four bills initially were referred to the Judiciary Committee for an assessment of their constitutionality. The Judiciary Committee issued a report deferring judgment on two bills and concluding that the other two were unconstitutional. H.R. REP. No. 1880, 49th Cong., 1st Sess. 4 (1886). With some parliamentary legerdemain, members of Congress who supported the dairy cause engineered the referral of one bill to the Agriculture Committee, a favorable forum, instead of the Revenue Subcommittee of the Ways and Means Committee, which had a stronger claim to jurisdiction. The Agriculture Committee was given jurisdiction over the measure by a direct vote of the House. H.R. REP. No. 2028, supra note 173, at 1.

231. See 17 Cong. Rec. 4930 (1886) (remarks of Rep. Price). Each of these states was among the nation's top twelve dairy states in 1886. See supra note 170.

232. See 17 CoNG. Rec. 4931 (1886).

233. See 1886 Hearings, supra note 15, at 144 (statement of A.M. Fuller, representing the Pennsylvania State Dairymen's Association); id. at 167 (statement of W.S. Truesdell, representing the Mississippi Valley Dairy and Creamery Association).

234. See id. at 10 (statement of James Hughes of the Produce Exchange of Baltimore City); id. at 17 (statement of W.H. Duckworth, commission merchant and dairy farmer); id. at 27 (statement of S.P. Hibbard, commission merchant); id. at 130 (statement of Col. R.M. Littler, secretary of the Chicago Produce Exchange).

235. See id. at 20 (statement of B.F. Van Valkenburgh, assistant dairy commissioner of New York).

236. See id. at 25 (statement of W.P. Richardson).

237. See id. at 201 (statement of G.W. Simpson).

238. See supra notes $39-92$ and accompanying text.

239. See, e.g., 1886 Hearings, supra note 15, at 173 (statement of Irus Coy, representing the Chicago Live Stock Exchange); id. at 195 (statement of Howard M. Holden of the Kansas City Live 
ter forces, the proinargarine interests found theinselves unable to inuster a powerful and concerted defense of their product. One company, Armour \& Co., which at that time was the largest margarine producer nationwide, organized inuch of the opposition to the bill. ${ }^{240}$ The margarine interests proved ineffective because they had not developed patterns of cooperation and joint action. Aside froin their desire to protect the margarine business, livestock owners, cotton growers, and inargarine inanufacturers shared few interests.

The bill's proponents mustered a variety of ostensibly legitimate arguinents on its behalf. First, they charged that margarine was a threat to the public health ${ }^{241}$ _an arguinent that had already been extensively rehearsed in battles with the margarine interests at the state level. The pro-dairy legislators dutifully repeated the familiar slanders about dead animals and Bright's kidney disease. ${ }^{242}$

In addition, someone in the pro-dairy camp looked up the various patents for margarine, all of which histed shightly different ingredients to avoid infringing on the original Mège-Mouries process. The ingredients listed in the patents for these different inargarines included a variety of revolting and dangerous substances, including nitric acid, sulphuric acid, carbohic acid, and caustic soda. ${ }^{243}$ Proponents of the inargarine tax read from this list in the congressional debates to suggest that margarine was unhealthful. ${ }^{244}$ In fact, however, few of these patents were actually used in margarine production, and inost of the offensive ingredients were simply acids used in the processing of the animal fat and forned no part of the substance ultimately purveyed to the public. ${ }^{245}$

Stock Exchange); id. at 209 (letter from Wyoming Stock-Growers' Association); 17 CoNG. REC. 4898 (1886) (Pittsburgh Grain and Flour Exchange); id. at 4905 (Cotton-Seed Crushers' Association); id. at 4914 (Chicago Board of Trade); id. at 4970 (Knights of Labor); id. at 4971 (Union Stock Yard and Transit Company); id. at 5117 (Trades Assembly of Western Pennsylvania).

Retail grocers split on the bill, with an official representative from New York favoring the bill, see 1886 Hearings, supra note 15, at 163 (statement of Lawrence J. Callanan), and other retail grocers speaking against it, see id. at 194 (statement of J. Merrill Currier); id. at 233 (statement of George M. Harris).

240. See 17 Cong. Rec. 4903 (1886) (remarks of Rep. Hepburn) ("I am glad to say that the whole of this opposition emanates from a single house in the city of Chicago which manufactures $9,000,000$ pounds of this bogus butter"); $i d$. at 4919 (remarks of Rep. Morgan) (attributing virtually all of the arguments and petitions in opposition to the bill to Armour's influence); id. at 4914-15 (remarks of Rep. Dunham) (submitting affidavit of Philip D. Armour); id. at 4925 (remarks of Rep. Farquhar) (identifying Armour as the nation's largest margarine manufacturer); id. at 5124 (remarks of Rep. Parker) (citing press report that Armour's representatives had travelled to Cleveland to persuade the Knights of Labor to oppose the bill).

241. See, e.g., 17 CONG. REC. 4865 (1886) (remarks of Rep. Scott).

242. See 17 CONG. REC. 4869 (1886) (remarks of Rep. Hopkins); id. at 4931 (report of House Committee on Agriculture).

243. See id. at 4931 (1886) (report of House Committee on Agriculture).

244. See, e.g., id. at 4868 (remarks of Rep. Hopkins); id. at 5129 (remarks of Rep. Evans).

245. See 1886 Hearings, supra note 15, at $96-97$ (remarks of Professor James F. Babcock). 
Second, proponents urged that the bill was necessary to prevent the fraudulent passing-off of margarine as butter. ${ }^{246}$ Although this argument could have supported the labelling provisions, it could not easily justify taxation, the feature most desired by the dairy industry. Further, the bill's proponents did not explain convincingly why state legislation was not the more appropriate means of preventimg fraud.

Third, proponents urged that the bill was legitimately framed as a revenue measure. ${ }^{247}$ The need for extra revenue seemed debatable, however, because the government had enjoyed a surplus the previous year. ${ }^{248}$ There was some reason to believe that 1887 would bring a revenue shortfall. ${ }^{249}$ Still, a tax of ten cents per pound was unlikely to raise much revenue because it would increase the cost of margarine to the point where it could not compete with butter. Opponents of the measure thus repeatedly denounced the purported revenue justification as sham. ${ }^{250}$

Fourth, proponents claimed that the bill was needed to preserve the dairy industry, a "great national industry" and "one of the chief industries of the country."251 They failed to explain, however, why the dairy industry merited special protection, particularly when protecting the dairy industry would inflict harm on another domestic industry.

Opponents charged that the measure was obviously intended to stamp out the margarine industry to protect and benefit the dairy industry. ${ }^{252}$ They claimed that such a motive was morally illegitimate and constitutionally suspect. Although proponents usually denied that they intended to enact class legislation designed to protect one domestic industry against competition from another, the charge had considerable substance. A contemporary political scientist, Henry C. Bannard, observed that House and Senate leaders "rushed the bill through, with the avowed determination of enhancing the price of butter for the sole benefit of those engaged in the manufacture of this one article."253

Even the bill's proponents admitted in candid moments that it constituted class legislation. In the words of Congressman Scott of Pennsylvania, a chief supporter of the bill, "[h]aving done this much for itself without the fostering aid of class legislation, the great farming interest

246. See, e.g., 17 Cong. REc. $4865-66$ (1886) (remarks of Rep. Scott).

247. See, e.g., id. at 4927 (remarks of Rep. Price).

248. See id. at 5076 (remarks of Rep. McCreary); id. at 4936 (remarks of Rep. Wilson).

249. See id. at 4904 (remarks of Rep. Henderson) (quoting a report from the Secretary of the Treasury estimating a deficit of $\$ 24,600,000$ for the fiscal year ending June 30,1887 ).

250. See, e.g., id. at 4936 (remarks of Rep. Wilson); id. at 4972 (remarks of Rep. Morrison); id. at 4898 (remarks of Rep. Mills).

251. See, e.g., id. at 4865,4867 (remarks of Rep. Scott).

252. See, e.g., id. at 4871 (remarks of Rep. Reagan) ("[t]he object is clearly to legislate in favor of one class of people and against another class"); id. at 5050 (remarks of Rep. Browne) (the bill "destroys competition and robs one citizen to put the money in the pocket of another").

253. Bannard, The Oleomargarine Law, 2 PoL. Sc1. Q. 545, 554 (1887). 
may rightfully msist upon a hearing when it appeals for protection against an msidious foe whose further advancement must mevitably destroy its chief support."254 Others were equally frank. One New Yorker remarked that "[t] $]$ his oleomargarine busmess is a bad busmess ... and the sooner it is exterminated the better it will be for us."25s A member from Wisconsin opposed any reduction in the proposed tax, arguing that a lower tax "might not accomplish the object that I am free to say mclines me to the support of the measure under consideration, for I fly the flag of an intent to destroy the inanufacture of the noxious compound by taxing it out of existence."256

Confronted with overwhelming political support for the dairy cause, the margarine interests realized that they could not stop passage of some forin of antimargarine legislation. They adopted the strategy of trymg to amend the bill to eliminate or drastically reduce its most offensive feature-the prohibitory tax. ${ }^{257}$ On balance, this strategy proved quite successful. The House halved the margarine tax to flve cents per pound, ${ }^{258}$ and the Senate dropped the tax to two cents per pound. ${ }^{259}$ In other respects, however, the bill emerged from Congress much as the dairy industry had proposed, with provisions for labelling, forfeiture, and licensing. It passed the House by a vote of 177 to $101^{260}$ and the Senate by a vote of 37 to $24 .{ }^{261}$

The bill was then presented to President Cleveland for his siguature. The margarine and butter forces descended on the White House with a vengeance, the former claiming that the bill was the worst sort of class legislation, the latter proclaiming the absolute necessity of the bill as a means of protecting the dairy farner against rumous competition from counterfeit butter. ${ }^{262}$ Many petitioners did not even bother to disguise their motives as public-spirited; as the President dryly observed, "those on both sides of the question whose advocacy or opposition is based upon

254. 17 CONG. REC. 4866 (1886).

255. Id. at 4894 (remarks of Rep. Millard).

256. Id. at 5082 (remarks of Rep. Hudd); see also id. at 4872 (remarks of Rep. Hiscock) (acknowledging that the bill "may possibly have the effect of stamping [the margarine] industry out of existence").

257. See, e.g., id. at 5209 (vote on amendment that would have reduced the tax to three cents a pound). At least one pro-dairy legislator strongly suggested that the bill's proponents would agree to reduction in the size of the tax so long as the principle of taxing oleomargarine were accepted. See id. at 4868 (remarks of Rep. Hopkins) ("I would not imperil [the bill's] passage in the House by obstinately adhering to the tax of 10 cents per pound ... where some other member, actuated by honest inotives, as I presume him to be, should feel that 2 or $5 \notin$ per pound is as much as should be imposed").

258. Id. at 5210 .

259. Id. at $7201-02$.

260. Id. at 5213 .

261. Id. at 7202.

262. See H.R. Exec. Doc. No. 368, 49th Cong., 1st Sess. 1-2 (1886). 
no broader foundation than local or personal interest have outnumbered all the others."263 One Washington paper, in a humorous editorial, pictured the President histenmg to a barnyard convention in the White House back lot, describing his sensations as he listened to the cackle of the hens and the lowing of the cows and overheard their discussions of how they would punish him politically if he did not sign the measure. ${ }^{264}$ The press showed intense interest in the bill, with speculation rife as to whether the President would sign or veto. ${ }^{265}$ Opinion was evenly split between the view that the President favored the bill but was going to veto it, and that he was conscientiously opposed to it but had decided to sign it. $^{266}$

Eventually the President signed the bill, issuing an explanation that courageously managed to credit the arguments made by all sides to the controversy. ${ }^{267}$ The President acknowledged that if the matter were presented to him as an initial matter he might doubt the need for additional taxes, and he agreed that if the real purpose of the measure were "to destroy, by the use of the taxing power, one industry of our people for the protection and benefit of another," he would doubtless veto the measure. ${ }^{268}$ But, said the President, in this context his function involved deference to a coordinate branch of government, and he was not entitled to indulge any suspicions of improper motives on Congress' part. After bowing to the margarine forces, the President then paid his respects to the butter interests by mouthing the usual platitudes about hard-working farmers and the virtues of butterfat. ${ }^{269}$ One waggish newspaper declined a reader's request that the President's message be reproduced in full, observing that the full text could be summarized as follows: "For many obvious reasons this bill should not become a law. I therefore return it approved to the body in which it originated."270

\section{The 1886 Statute in Perspective}

Prosaic as it may have been in subject matter, the Margarine Tax Act of 1886 represents something of a watershed in American politics. It was among the first instances of federal legislation in which one domestic industry sought to enlist the government's coercive power to stamp out

263. Id. at 1 .

264. See The Oleomargarine Bill: Hearings on H.R. 3717 Before the Senate Comm. on Agriculture and Forestry, 56th Cong., 2d Sess. 396 (1901) (remarks of Henry E. Davis) (describing the newspaper editorial).

265. See Washington Post, July 31,1886, at 1 , col. 8 (describing a stir among the press corps when the Speaker of the House received a message thought to be a veto of the margarine bill).

266. Washington Post, July 31,1886 , at 2, col. 1.

267. H.R. EXEC. Doc. No. 368, supra note 262, at $1-4$.

268. Id. at 2.

269. Id.

270. Bannard, supra note 253 , at 557. 
competition from another domestic imdustry. The imvolvement of smaller banks in Andrew Jackson's campaign to abohish the Second Bank of the United States might provide the closest analogy. ${ }^{271}$ That campaign, however, was not spearheaded by smaller banks as an organized group. ${ }^{272}$ Tariff legislation, with its long history of discrimination against foreign industry for the protection of domestic interests offers another analogy. ${ }^{273}$ But tariff laws had always been directed against foreign interests, and are thus distinguishable from a statute designed to protect one doinestic imdustry against coinpetition from another. The margarine tax also bore a certain reseinblance to the various types of federal sumptuary legislation that discriminated against items or activities considered to be morally questionable, such as alcohol and tobacco. ${ }^{274}$ But this type of legislation targeted products that were at least arguably harmful in their own right. In the case of margarine, once the bogus health argument was put aside, the only harm imvolved was the weakening of the butter market. Advocates of the bill also cited laws banning counterfeit currency ${ }^{275}$ - a spurious analogy, at best, to a proposal taxing margarine (or "counterfeit butter") out of existence.

The bill's opponents repeatedly emphasized its unusual nature. ${ }^{276}$ They warned that if the statute were enacted, the principle of protection would have no logical stopping place. ${ }^{277}$ If the dairy imdustry could be

271. See B. Hammond, Banks and Politics in America: From the Revolution to the Crvil WAR 405-450 (1957).

272. See id.

273. Dairy forces used this analogy in debate on the bill. See, e.g., 17 CoNG. REc. 4894 (1886) (remarks of Rep. Millard).

274. See id. at 4894 (remarks of Rep. Millard).

275. See, e.g., id. at 4977 (remarks of Rep. Milliken).

276. See id. at 4870 (remarks of Rep. Hammond) ("never have we undertaken to give protection to one individual of our own people as against another mdividual of our own people"); id. at 4917 (remarks of Rep. Glass) ("[t]he Government of the United States has no right to tax an industry out of existence, or to tax one industry oppressively for the benefit of another"); id. at 5056 (reniarks of Rep. Butterworth) (asking whether the "time has come when you are willing to wipe out one legitimate domestic industry which but for your antagonistic legislation might survive and flourish, to wipe it out simply because it is the competitor of another domestic industry").

277. See, e.g., id. at 4914 (renuarks of Rep. Dunham) ("if we, by legislation or by taxing a product in order to force up the price of butter, can succeed in this case, in the next Congress another large interest or large class in the country will apply to us to tax something else, so that they can keep up the price of their product"); $i d$. at 4936 (remarks of Rep. Wilson) ("[o]nce we establish the principle that the sovereign power of taxation with which the people intrust their servants can be perverted from its only honest purpose of raising taxes, and be used to oppress, to suppress, or to destroy the industry of any class of our citizens in order to increase the profits of the industry of any other class of our citizens, and this ceases to be a government of equal laws and becomes at once a government of privileged classes and oceupations"); id. at 5050 (remarks of Rep. Browne) ("[t]his bill seeks a class legislation in its present shape of the most pronounced type. A great danger lurks under its thin di[s]guises; it makes a precedent which may be at any time employed to destroy the weak in the interest of the strong. The theory upon which this bill proceeds may be used to justify any legislative monopoly however nonstrous or exacting"); id. at 4898 (remarks of Rep. Mills) ("[i]f you can destroy [the margarine] imdustry, you can destroy any other by abusing the power of 
protected agamst margarine, then cotton might seek protection against wool, or one grade of butter against another grade of butter. As the bill approached passage, its opponents sought to delay matters by introducing facetious amendments for the protection of various items of commerce against competition by new technology. One Congressman proposed to impose a puritive tax on the manufacture and sale of glass eggs, so "that the great American hen may be properly protected."278 Although these remarks were humorous, they served the serious purpose of illustrating the effects of protecting one domestic industry against competition from another more technologically advanced industry, if taken to its logical conclusion.

These dangers were not merely theoretical. Political scientist Henry C. Bannard warned that legislation of this sort was already gaining favor in state legislatures. A bill introduced into the Ohio legislature would have prohibited the consumption of beef slaughtered and dressed outside the state. In Illinois, the coopers' union sought the passage of legislation prohibiting the use of second-hand flour barrels and butter flrkins. ${ }^{279}$ Once lawmakers opened the Pandora's box of domestic protection, the types of legislation sought would be limitless.

If protectionist legislation of this sort were allowed, the power of special interest political lobbies would obviously be greatly enhanced. Several members of Congress commented on the power that the special interests had already gained in the legislative process. As one Congressman remarked:

I am amazed, I lack words to express my astonishment, that the American Congress could be absolutely converted, deliberately converted, into a great wrestling-ground, a gymnasium where all the business athletes of the country come to wrestle for supremacy, a prize-ring where jobbers come to blows and where the big jobs knock the little jobs out."280

Members of Congress understood that the sudden einergence of the dairy lobby represented something new in American politics. Several members lamented the fact that power was seeping away from meinbers who voted according to their individual consciences to groups of constituents who pressured their representatives. Senator Vance was not far from the mark when he punned that "butter, like conscience, [had] made

taxation"); id. at 5091 (remarks of Rep. Daniel) ("in this bill is the doctrine that Congress may create monopoly, and may help monopoly to crush out and destroy every wholesome industry" that is opposed by superior political force); $i d$. at 5156 (remarks of Rep. Wellborn) ("there cannot be found in all the history of the Republic a more dangerous precedent than that which the enactment of this bill ... . would establish").

278. Id. at 5010-11.

279. Bannard, supra note 253 , at 545 .

280. 17 Cong. Rec. 4918 (1886) (remarks of Rep. Dunn). 
cowherds of them all."281 Another Senator who voted for the measure said that "it is an outrageous bill, but we have got to vote for it. We do so in the hope and belief that the Supreme Court will declare it unconstitutional."282 Political scientist Henry Bannard agreed that this legislation was unprecedented, observing that "[t]]his enactment . . . marks a new era in our pohitical history. It widens the spleere of sumptuary legislation, einphasizes the interference theory of government, and extends the doctrine of protection to domains never before reached in our history."283

As one of the first successful efforts by one domestic imdustry to obtain federal legislative protection against competition from another, the margarine tax statute of 1886 marks the birth of the modern special interest state. The period between 1875 and 1900 constituted the great forinative era of industrial imterest groups: meat packers, ${ }^{284}$ cattlemen, ${ }^{285}$ wool growers, ${ }^{286}$ butchers, ${ }^{287}$ coopers, ${ }^{288}$ and many other imdustrial groups formed associations during this period, all of them dedicated to protecting their markets from competition througl tle apphication of government force. Before 1875, interest groups in the modern sense were unusual; after 1900 they were ubiquitous.

Why was this quarter-centnry the fornative period for modern political lobbies? Two forces may have produced the growtli of special imterest groups: first, the rapid imdustrialization of the American economy during this period, which disrupted established livelihoods and occupations; ${ }^{289}$ and second, the return to norinalcy following the Civil War and Reconstruction, which encouraged a focus on narrow self-interest that had been temporarily set aside during the war's cataclysnnic events. The growth of special interest politics during this period is a topic that might usefully be addressed in a study broader in scope than this Article.

\section{CONCLUSION}

The dairy industry's early cainpaign against margarine illustrates the complex interplay of markets, technology, politics, and law in Ameri-

281. See Washington Post, July 20, 1886, at 2, col. 3.

282. Washington Post, July 21, 1886, at 2, col. 1 .

283. Bannard, supra note 253 , at 546.

284. See R. Clemen, The AMERICAN Livestock AND MEAT INDUSTRY 802-03 (1923).

285. See 1886 Hearings, supra note 15, at 209.

286. See S. Misc. Doc. No. 99, 49th Cong., 1st Sess. (1886).

287. See R. ClEMEN, supra note 284 , at $242-43$.

288. See Bannard, supra note 253, at 545.

289. See M. Sklar, The Corporate Reconstruction of American Capitalism, 18901916: the Market, the Law, and Politics (1987); I. Tarbell, The Nationalizing of BUSINESS 1878-98 (1936). 
can society of the time. Among the first efforts by a doinestic industry to stainp out competition from another domestic industry, the story of that campaign presents a useful case history for the theory of public choice.

This Article has analyzed the early antimargarine battles to explore three fundamental questions. First, given organizational costs and freerider effects, how did a mass of five million dairy farmers and many thousands of factory owners and merchants coalesce so quickly into a potent pohitical interest group? This Article shows that the mdustry succeeded in forging an effective lobby by drawing on a well-developed set of preexisting institutions, such as factory owners, state and local dairy associations, boards of trade and produce exchanges, and at least one producers' cartel, which had been formed for nonpolitical purposes such as stimulating deinand for dairy products or correcting market failures.

Second, how did the basic structural features of the American political system-federalisin and separation of powers-affect the growth and developinent of special interest lobbies? The Article demonstrates that federahisin generally facilitated interest group activity, because states could act as laboratories for the development of anticompetitive legislation, and because the interest group could achieve two layers of protection in a federal system. The effect of federalisin was not unambiguous, however, because states could provide havens for inargarine inanufacture and because two levels of protection may have required greater resources than a umitary system. On the other hand, separation of powers generally hindered interest group activity because the group seeking protection had to enlist the active cooperation of three separate branches of governinent. Again, however, the effect was not unambiguous because the splintering of government authority into three branches allowed the interest group to concentrate its fire on the branch where the group's political resources were likely to be most influential.

Third, how did economic conditions in the industry affect the level of interest group activity? This Article suggests that the level of interest group activity was generally higher during depressed times than during prosperous times. The dairy industry initiated its antinargarine cainpaigns during times of falling butter prices: 1877 (first-generation state statutes), 1884 (second-generation state statutes), and 1886 (the federal statute). The industry did not mitiate campaigns in times of relatively high butter prices (1874-77, 1881-83), even though margarine sales were also high during these periods. Once a campaign had been initiated, however, the industry was able to sustain some momentum even in prosperous times, as demonstrated by the continuous enactinent of first-generation statutes in various states between 1881 and 1883 .

These observations, of course, are based on events in a single indus- 
try during a limited time frame. The Article, then, leaves open whether they hold true for other industries and other time periods. How these theories fare in other situations inay provide a potentially fruitful subject for further research. 
